\title{
WestVirginiaUniversity
}

THE RESEARCH REPOSITORY @ WVU

Graduate Theses, Dissertations, and Problem Reports

2006

\section{Sulfate sorption of acidified forest soils in the Otter Creek Wilderness Area}

Autumn Leah Bryson

West Virginia University

Follow this and additional works at: https://researchrepository.wvu.edu/etd

\section{Recommended Citation}

Bryson, Autumn Leah, "Sulfate sorption of acidified forest soils in the Otter Creek Wilderness Area" (2006). Graduate Theses, Dissertations, and Problem Reports. 2386.

https://researchrepository.wvu.edu/etd/2386

This Thesis is protected by copyright and/or related rights. It has been brought to you by the The Research Repository @ WVU with permission from the rights-holder(s). You are free to use this Thesis in any way that is permitted by the copyright and related rights legislation that applies to your use. For other uses you must obtain permission from the rights-holder(s) directly, unless additional rights are indicated by a Creative Commons license in the record and/ or on the work itself. This Thesis has been accepted for inclusion in WVU Graduate Theses, Dissertations, and Problem Reports collection by an authorized administrator of The Research Repository @ WVU. For more information, please contact researchrepository@mail.wvu.edu. 


\section{Sulfate Sorption of Acidified Forest Soils in the Otter Creek Wilderness Area}

Autumn Leah Bryson, B.S.

Thesis Submitted to

The Davis College of Agriculture, Forestry and Consumer Sciences

at West Virginia University

In partial fulfillment of the requirements for the degree of

Master of Science

in

Plant and Soil Science

Louis M. McDonald, Ph. D., Chair

James A. Thompson, Ph. D

Dorothy J. Vesper, Ph. D

Division of Plant and Soil Sciences

Morgantown, WV

2006 


\title{
Abstract
}

\section{Sulfate Sorption of Acidified Forest Soils in the Otter Creek Wilderness Area}

\begin{abstract}
Autumn Leah Bryson
Acid deposition has caused tremendous stress to forest ecosystems. Increased soil acidification due to acidic inputs from acid deposition may cause declines in forest productivity through the depletions of soil nutrients, increased mobility of aluminum and increases in acid anion concentrations, primarily nitrate and sulfate. The retention of sulfate in soil is a critical mechanism regulating soil acidification. Sulfate adsorption acts as a buffer delaying the elevation of solution sulfate concentrations. A soil will continue to adsorb sulfate until all the sites are filled and sulfate saturation is reached at which point leaching resumes. Therefore it is important to measure the sulfate adsorption potentials and saturation point in forest soil. The lack of method standardization makes it difficult to compare sulfate adsorption with other soils. Sulfate adsorption capacities of forest soils in the Otter Creek Wilderness Area of the Monongahela National Forest were determined using the adsorption isotherm method and the single point method. However a new two-point method was identified that measures the sulfate adsorption. This method was able to determine the maximum sulfate adsorption capacity while still accounting for oversaturation.
\end{abstract}




\section{Table of Contents}

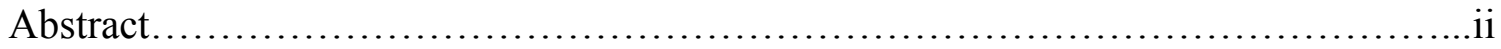

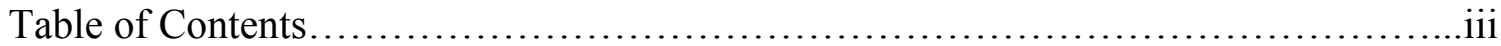

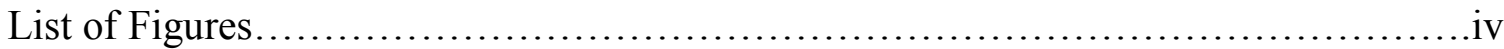

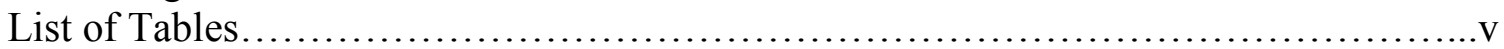

Acknowledgements........................................................vi

Chapter 1

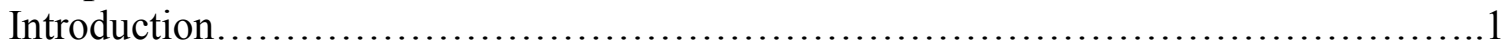

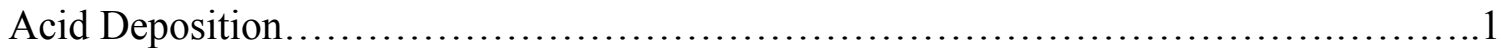

Formation, Distribution, and Composition...................................... 1

Chemical Effects on Soil..........................................................

Chapter 2

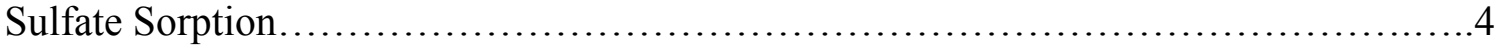

Factors Affecting Sulfate Sorption.................................................

Chapter 3

Methods to Quantify Sulfate Sorption.......................................... 16

Objectives.................................................................. 17

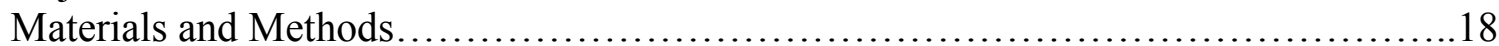

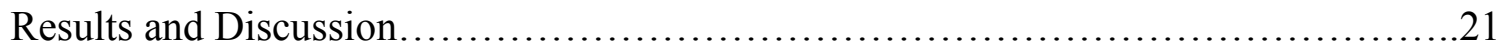

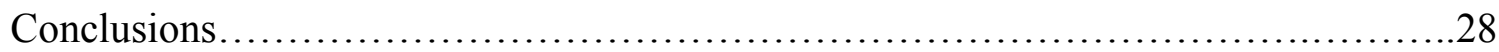

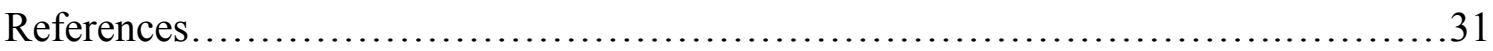




\section{List of Figures}

Figure 1.1 Formation of acid deposition from the combustion of fossil fuels.............2

Figure 1.2 National Atmospheric Deposition Program sulfate trends in the U.S...........2

Figure 1.3 National Atmospheric Deposition Program nitrate trends in the U.S. ..........3

Figure 1.4 Emission Sources Precipitation Acidity in the United States.....................

Figure 2.1 Stability relationships in the $\mathrm{Al}_{2} \mathrm{O}_{3}-\mathrm{H}_{2} \mathrm{SO}_{4}-\mathrm{H}_{2} \mathrm{O}$ system.....................

Figure 2.2 Formations of outer sphere and inner sphere surface complexes..............8

Figure 2.3 Surface charge versus $\mathrm{pH}$ and ionic strength............................ 12

Figure 2.4. Distribution of acid Deposition in West Virginia and Surrounding Areas....14

Figure 2.5 Trends in sulfate concentration at NADP site WV18.................... 15

Figure 3.1 Site locations in the Otter Creek Wilderness Area........................... 19

Figure 3.2 Isotherm lines for all four soils......................................24

Figure 3.3 Relationship between isotherm, two point, and single point method...........26

Figure 3.4 Gibbsite-Alunite solubility relationships................................ 


\section{List of Tables}

Table 1.1 Stability Constants of complexes created in the soil.........................5

Table 2.1 Ionic strength of soil solutions from a few selected surface soils...............10

Table 3.1 Extractable and adsorbed sulfate in the top B horizon .......................17

Table 3.2 Selected properties of soils used in the study........................... 18

Table 3.3 Clay mineralogy for each pedon used in this study......................... 19

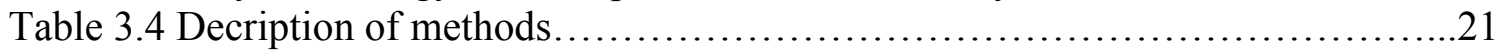

Table 3.5 Presence of iron and aluminum oxides in the soil..........................22

Table 3.6 Extractable sulfates using single and multiple phosphate extractions...........22

Table 3.7 Single point and isotherm estimates of sulfate adsorption capacities...........23

Table 3.8 Percent error for single point and two point methods at different sulfate

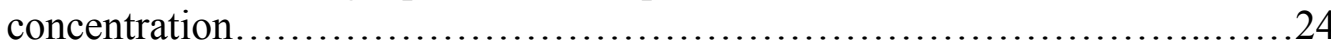

Table 3.9 Comparison of adsorption potentials for different soils....................28 


\section{Acknowledgements}

This study would not have been possible without the assistance of many individuals to whom I am forever grateful. I would like to thank the Division of Plant and Soil Science for funding my research. My deepest appreciation is extended to my mentor, my hero, and my advisor, Dr. Louis M. McDonald, for sharing his knowledge and wisdom with me, believing in me, and always pushing me towards excellence. I would also like to express my gratitude to my committee members, Dr. James A. Thompson and Dr.

Dorothy J. Vesper for all their contributions towards my studies. I am also grateful for the guidance of Stephanie Connolly and the United States Forest Service. I greatly appreciate all the help and laboratory assistance of Joan Wright and Rajesh Chintala. Last but certainly not least I would not have been able to accomplish so much without the love and support of my friends and especially my family. That being said, I would like to dedicate this thesis to the memory of my grandfather, Donald E. Thwaits 


\section{Chapter 1}

\section{Acid Deposition}

Precipitation is naturally acidic with a $\mathrm{pH}$ of approximately 5.6. Water vapors react with carbon dioxide in the atmosphere to produce carbonic acid, a weak acid. Acid deposition, commonly referred to as acid rain, results from the formation of strong acids in the atmosphere. Precipitation with a $\mathrm{pH}$ below 5 is considered acid rain. This phenomenon is caused from the emissions of burning fossil fuels, primarily coal and oil. The main components of acid deposition are sulfur dioxides and nitrogen oxides. These ions react with water vapors in the atmosphere and undergo an oxidation reaction to produce nitric and sulfuric acid (Figure 1.1). Wind currents can carry these acidic vapors great distances, however they eventually fall to the earth's surface as wet or dry deposition (Figures 1.2 and 1.3). Climatic patterns often modify the distribution of acid deposition. Therefore, areas downwind from industrialized regions may experience more acidic precipitation than the areas immediately surrounding pollutant emission sources (Figure 1.4).

Higher elevations are subjected to increased acid inputs through greater precipitation and cloud deposition with acid fogs and mists. The acidity in precipitation can have detrimental effects on forest ecosystems. High elevation forest soils are extremely susceptible to alterations in the soil chemistry brought on by acid deposition (Johnson and Taylor, 1989; Matzner and Dise, 1998; Adams et al., 2000). The potential effects of prolonged exposure of forest soil to acidic precipitation have been identified as a major concern since compared to agricultural soils, forest soils are relatively unmanaged (Lee and Weber, 1982). Agricultural soil is not typically affected by acid deposition because it is already acidified from fertilizer application and is usually limed (Pierzynski et al., 2000), although there may be exceptions (McDonald and Balasko, 2003). Liming cultivated soils may overshadow acidic deposition influences; however, large areas of poorly buffered forest soils are significantly impacted by acid precipitation (Suarez and Jones, 1982). 


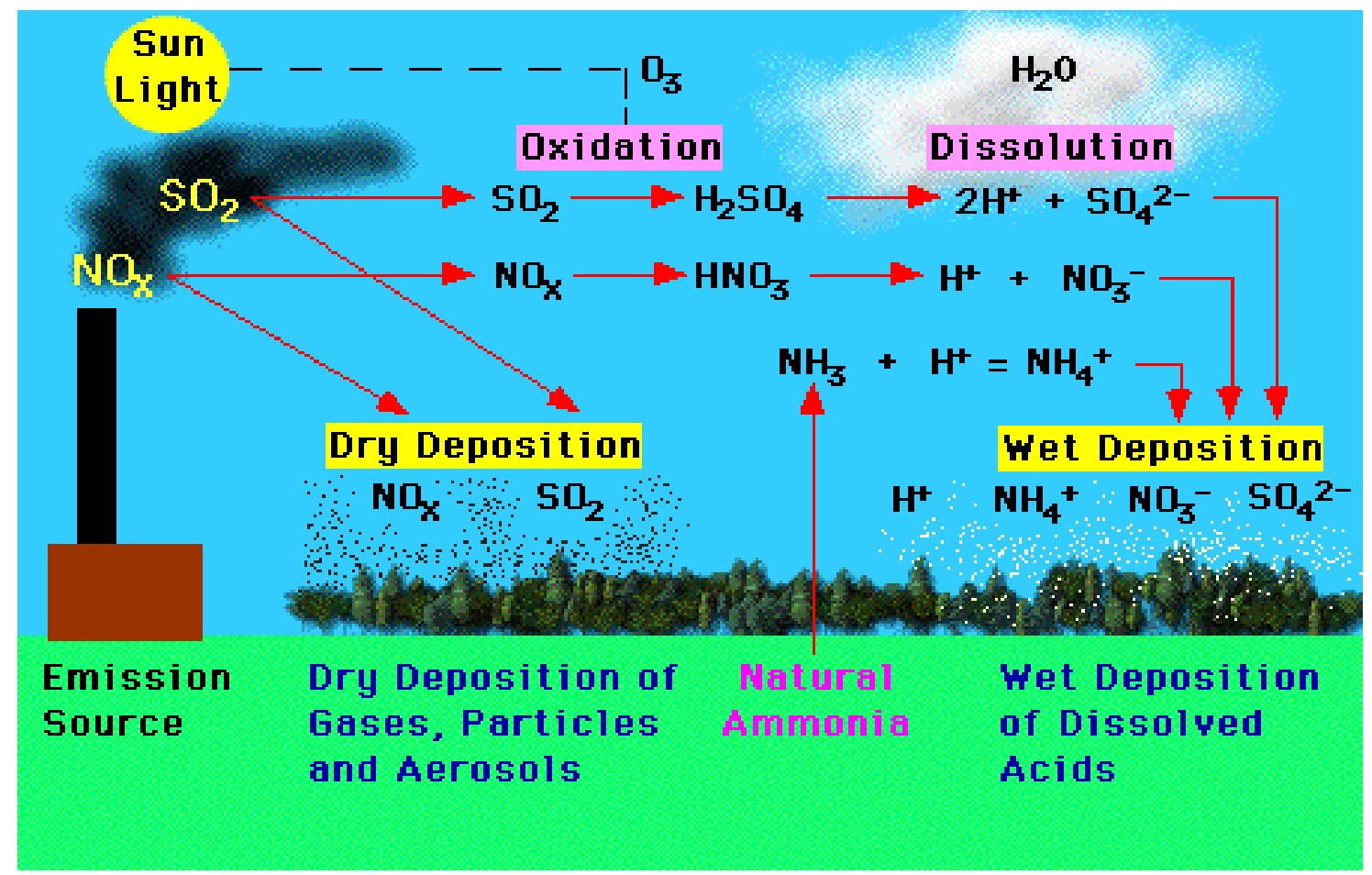

Figure 1.1 Formation of acid deposition from the combustion of fossil fuels (Pidwirny, 2006)

\section{Sulfate ion wet deposition, 2004}

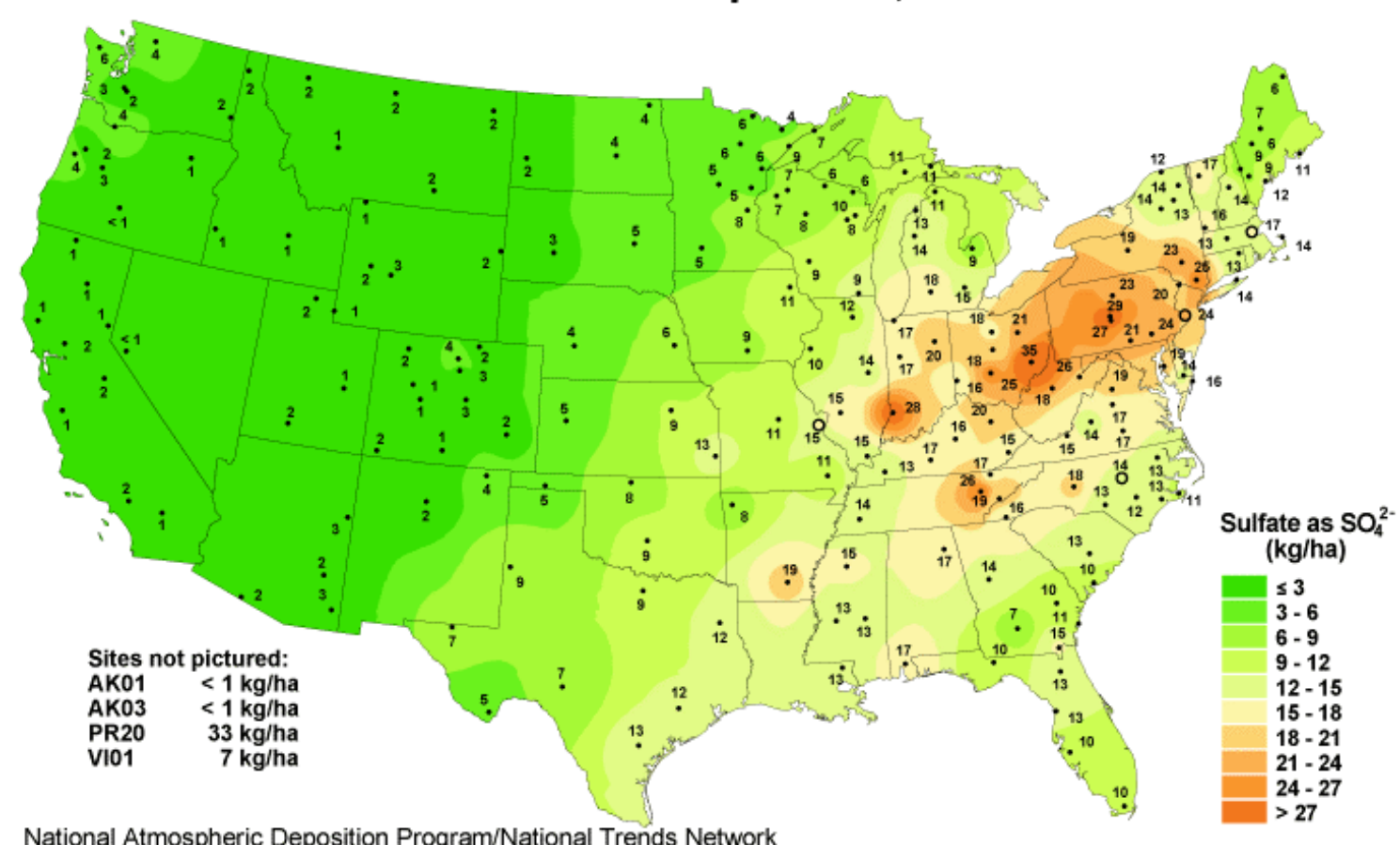

National Atmospheric Deposition Program/National Trends Network http://nadp.sws.uiuc.edu

Figure 1.2 National Atmospheric Deposition Program sulfate trends in the United States (NADP, 2004) 


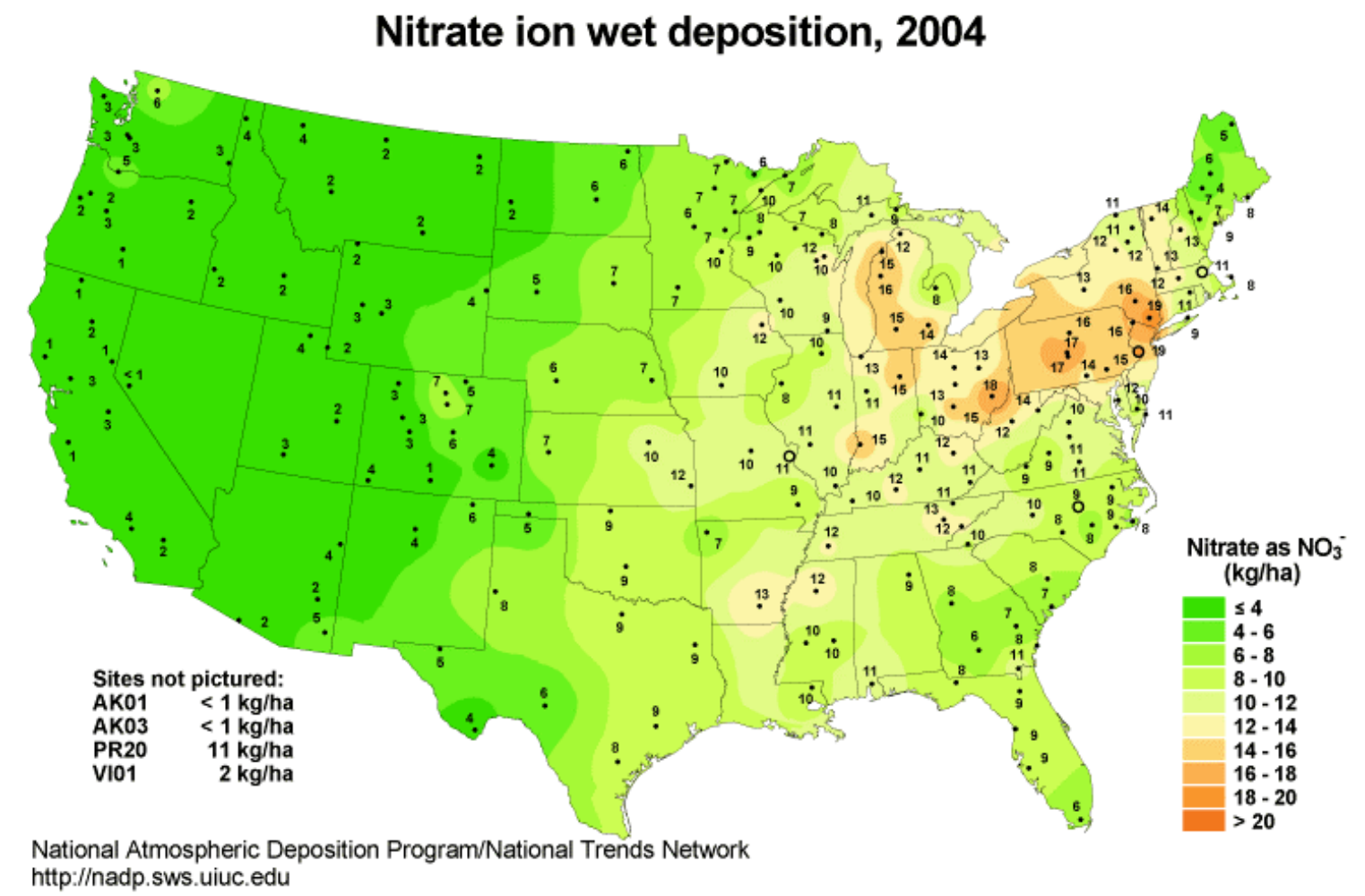

Figure 1.3 National Atmospheric Deposition Program nitrate trends in the United States (NADP, 2004)

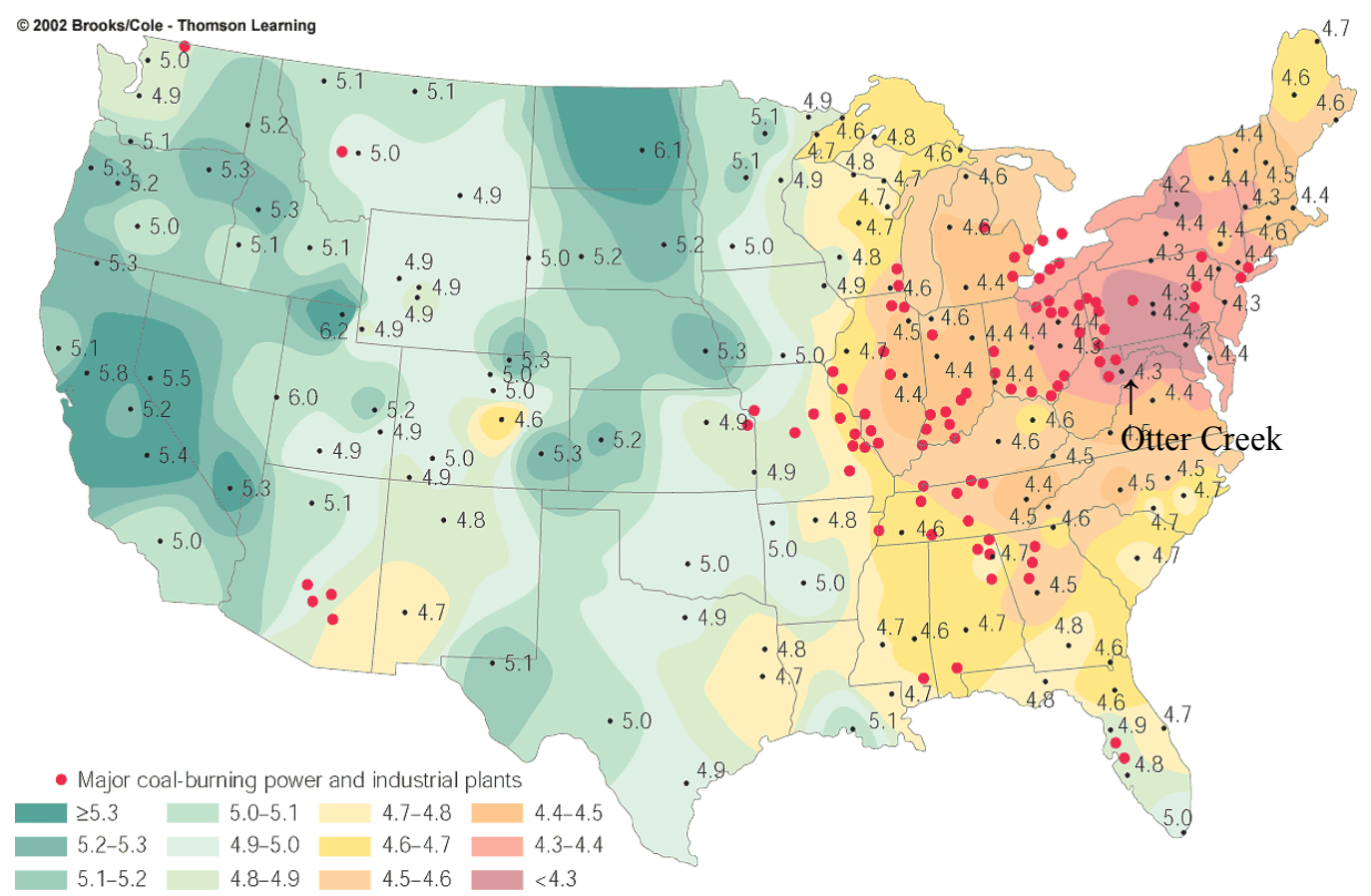

Figure 1.4 Emission sources and precipitation acidity in the Unites States (EPA, 2006) 
As forests mature, the soil becomes more acidic due to the uptake of alkaline cations and excretion of protons by the vegetation, and the release of organic acids during decomposition of organic matter. These soils tend to have a low buffering capacity attributable to their parent material. Forest soil formed on acidic parent material is especially vulnerable (Drever, 1997). Chemical weathering of parent material replenishes soil nutrients; however, when the parent material is chemically resistant bedrock, such as sandstone and shale, the rate at which nutrients are released is very slow. If the deposition rate is greater than the weathering rate then acidification is likely to occur (Drever, 1997).

Increased forest soil acidification due to acid deposition may cause reduced forest productivity leading to the decline of some tree species (Drohan and Sharpe, 1997), specifically Red Spruce (Picea rubens), Fraser Fir (Abies fraseri), Yellow Pine (Pinus Ponderosa), Sugar Maple (Acer saccharum), Yellow Birch (Betula alleghaniensis), White Ash (Fraxinus Americana), American Beech (Fagus grandifolia), White Spruce (Picea glauca), and Balsam Fir (Abies balsamea) (Mackenzie and El-Ashery, 1989). Acid deposition has caused tremendous stress to forest ecosystems through the depletion of soil nutrients, increased mobility of aluminum, and increased acid anion concentrations (Reuss and Johnson, 1986; Johnson and Taylor, 1989).

When acid deposition enters forest soil, the strong acids dissociate into hydrogen ions and nitrate and sulfate anions. The excess atmospheric hydrogen inputs cause an increase in soil acidity and accelerate mineral dissolution resulting in an increase in the mobilization of dissolved inorganic aluminum. This form of aluminum can be toxic to some vegetation (Cronan et al., 1989). With an increased amount of soluble aluminum, plants may absorb enough to reach toxic levels. Aluminum toxicity is most commonly encountered in forests containing sensitive tree species where root biomass is concentrated in mineral horizons with low base saturation, characterized by high inputs of acid deposition, low sulfate adsorption, and in ecosystems where drought stress has increased the dependence for deeper rooting (Cronan et al., 1989). Aluminum may also compete with cationic nutrients for cation exchange sites (Reuss and Johnson, 1986).

Soil contains positively charged ions such as calcium, magnesium, and potassium that are bound to the soil at exchange sites. These elements are essential plant nutrients; they also serve as a buffer for soil solution aluminum. The reduction of exchangeable 
cations occurs when the aluminum and hydrogen ions replace the cations on the exchange sites. To maintain electroneutrality, the nitrate and sulfate anions create complexes with the displaced cations and accompany them through the soil profile (Berger and Likens, 1999). The sulfate ion is more abundant in acid precipitation and it has a higher stability constant than the other anions (Table 1.1), so it is typically sulfate that is leached with the cations and transported through the soil (MacDonald et al., 1992). As the more mobile alkali cations are leached, the less mobile aluminum and iron are retained as exchangeable cations causing an increase in soil acidity and a decrease in soil fertility.

Table 1.1 Stability constants of some common soil solution complexes (Lindsay, 1979)

\begin{tabular}{lc}
\hline Complex & Log K \\
\hline $\mathrm{CaSO}_{4}{ }^{0}$ & 2.31 \\
$\mathrm{CaNO}_{3}{ }^{+}$ & -4.80 \\
$\mathrm{CaCl}^{+}$ & -1.00 \\
$\mathrm{MgCl}_{2}{ }^{0}$ & -0.03 \\
$\left.\mathrm{Mg} \mathrm{NO}_{3}\right)_{2}{ }^{0}$ & -0.01 \\
$\mathrm{MgSO}_{4}{ }^{0}$ & 2.23 \\
$\mathrm{Al}\left(\mathrm{NO}_{3}\right)_{3}{ }^{0}$ & 0.12 \\
$\mathrm{AlSO}_{4}{ }^{+}$ & 3.20 \\
\hline
\end{tabular}

The decrease in the concentration of alkali cations results in the reduction of the soils buffering capacity at moderate $\mathrm{pH}$ levels increasing the soils susceptibility for further acidification (Barton et al., 2002). Criteria used to assess soil sensitivity to nutrient depletion from acid deposition usually include cation exchange capacity, base saturation, $\mathrm{pH}$, and carbonate content. Although these criteria are important, sulfate adsorption potentials should also be included in assessments of soil sensitivity to acid deposition.

\section{Chapter 2}

\section{Sulfate Adsorption}

Among anionic components of acid precipitation, sulfate deserves special attention because it often predominates over other anions and it can accumulate in soils (Singh, 1984). Studies have shown that the retention of sulfate in forest soil is a critical process regulating soil acidification (Reuss and Johnson, 1986). Sulfate retention acts as a 
buffer delaying the elevation of sulfate concentrations in the soil solution. Sulfate adsorption limits sulfate ion transport; consequently decreased cation leaching has been observed in soils that adsorb sulfate (Huete and McColl, 1984). Because cations must balance anions in soil solution, soil sulfate adsorption effectively prevents any increase in cation leaching under heavy inputs of sulfuric acid (Johnson and Cole, 1979). By regulating mobile sulfate concentrations in soil, reductions in the transport of alkali cations can occur, and leaching of aluminum (Wolt, 1994) and hydrogen ions (Perrson, and Lövgren, 1996) can be controlled.

Huete and McColl (1984) demonstrated the influence of the anion composition of acid deposition on cation leaching. They showed that in soils possessing variable charge, the anion composition's effect on cation leaching was determined by two factors: the anion adsorption capacity of the soil profile and the nitrate to sulfate ratio of the acidic input. As the nitrate concentration increased, it interfered with sulfate adsorption and increased cation leaching. When there was only sulfate in the solution, the soil adsorbed most of the sulfate and leached cation concentrations were lower.

The various mechanisms responsible for sulfate retention in soil are the precipitation of low solubility iron and aluminum hydroxyl sulfate minerals, the reduction of sulfate by sulfur reducing bacteria, and sulfate adsorption onto soil particles (Hingston et al., 1972; Rajan, 1978; Johnson et al., 1979; Courchesne and Hendershot; 1990; Edwards, 1998). The minerals most likely to be significant with respect to sulfate and aluminum are alunite, basaluminite, and jurbanite (Figure 2.1). The formation of alunite $\left[\mathrm{KAl}_{3}(\mathrm{OH})_{6}\left(\mathrm{SO}_{4}\right)_{2}\right]$ and basaluminite $\left[\mathrm{Al}_{4}(\mathrm{OH})_{10} \mathrm{SO}_{4}\right]$ is thermodynamically favored in sulfate-containing acid environments, occurs at relatively low solution sulfate concentrations, and is enhanced in the presence of clay minerals (Wolt, 1981). The minerals alunite and jurbanite may be more stable than gibbsite in acidic sulfate systems (Drever, 1997). It is difficult to experimentally distinguish between sulfate precipitation and sulfate adsorption (Charlet, 1993; Drever, 1997). Both cause removal of acidity equivalent to removal of sulfate from solution (Drever, 1997). Sulfate adsorption has the advantage over precipitation in that it can maintain lower solution concentrations. There are two primary types of sulfate adsorption, non-specific and specific. 


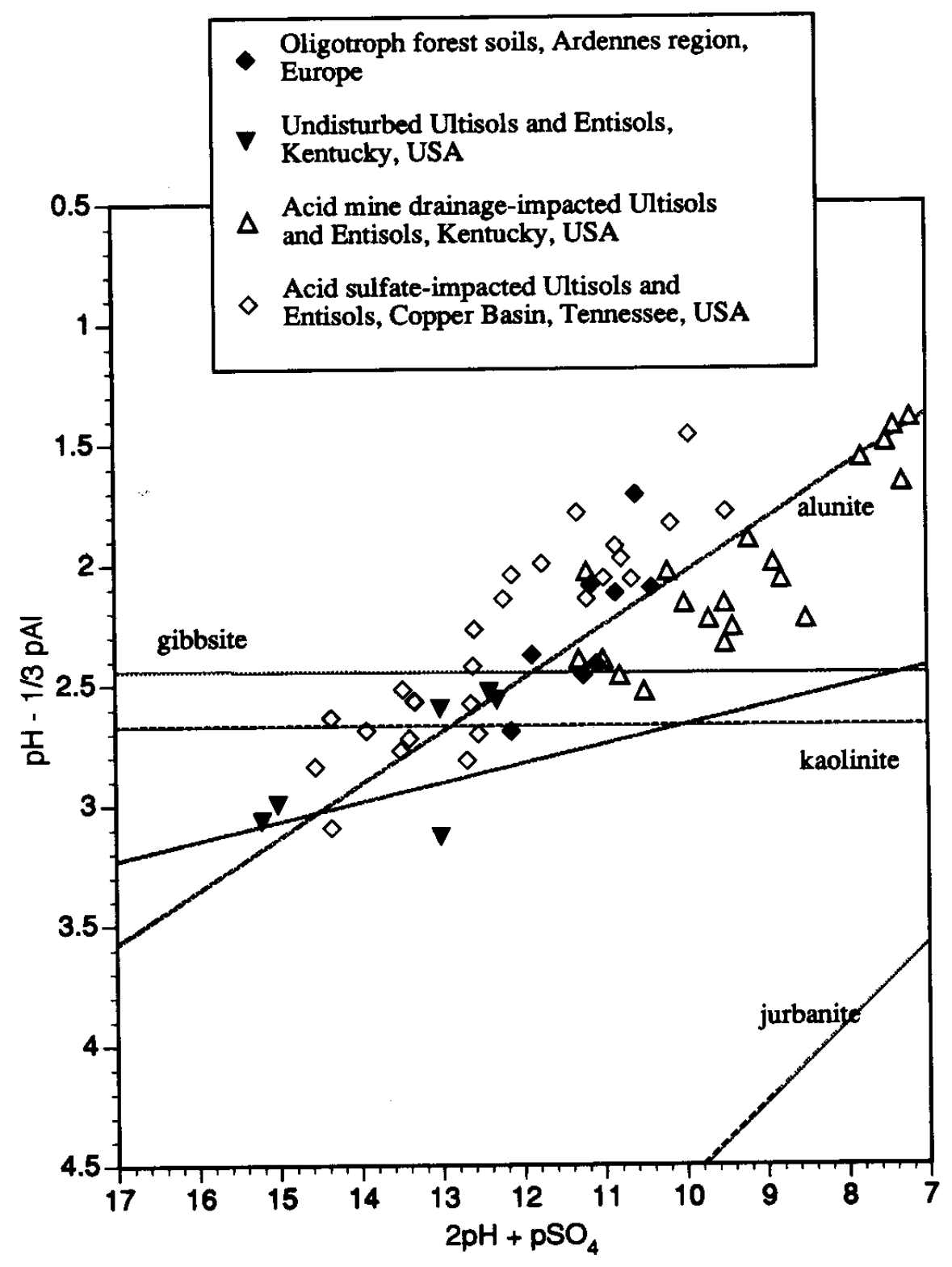

Figure 2.1 Stability relationships in the $\mathrm{Al}_{2} \mathrm{O}_{3}-\mathrm{H}_{2} \mathrm{SO}_{4}-\mathrm{H}_{2} \mathrm{O}$ system at $298.15^{\circ} \mathrm{K}$ and $101.3 \mathrm{kPa}$, superimposed on compositions of soil solutions exposed to anthropogenic acid sulfate. Soil solution compositions are from Wolt (1981), Van Praag and Weissen (1985), and Karanthanansis et al. (1988) (Wolt, 1994).

Non-specific adsorption, also known as outer sphere complexation, results from an electrostatic attraction between the negatively charged sulfate ion and a positively charged surface particle. As the $\mathrm{pH}$ decreases the excess hydrogen creates a positive charge on surfaces of organic matter, layer silicates, oxides, and hydrous oxides. In nonspecific adsorption the anion is held as a counter-ion in the diffuse double layer next to 
the positively charged colloidal surface. A hydration sphere typically separates the sulfate anion and the soil surface (Figure 2.2). If the sulfate is retained by electrostatic forces, the soil will have a limited adsorption capacity (Charlet et al., 1993). However, non-specific adsorption can still buffer the impacts of acid sulfate inputs. Desorption of nonspecifically adsorbed sulfate can occur through increases in $\mathrm{pH}$, decreases in the concentration of the sulfate input, or the addition of anions with a higher affinity for adsorption sites.

Specific adsorption or inner-sphere complexation occurs when a direct chemical bond forms between the adsorbing sulfate anion and a metal ion at the soil surface (Figure 2.2). The sulfate anion displaces another anion, a process commonly referred to as ligand exchange. When sulfate is adsorbed to a soil exchange site, the hydroxide released can react with protons to free a site for cation adsorption (Hodges and Johnson, 1987). Therefore, specific adsorption can create new cation exchange sites. The amount of hydroxide released will vary with the amount of sulfate adsorbed on the surface

\section{Outer-Sphere}
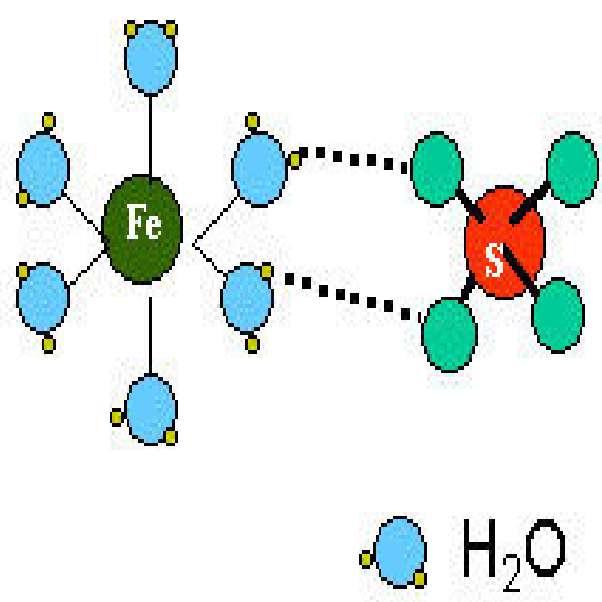

Inner-Sphere
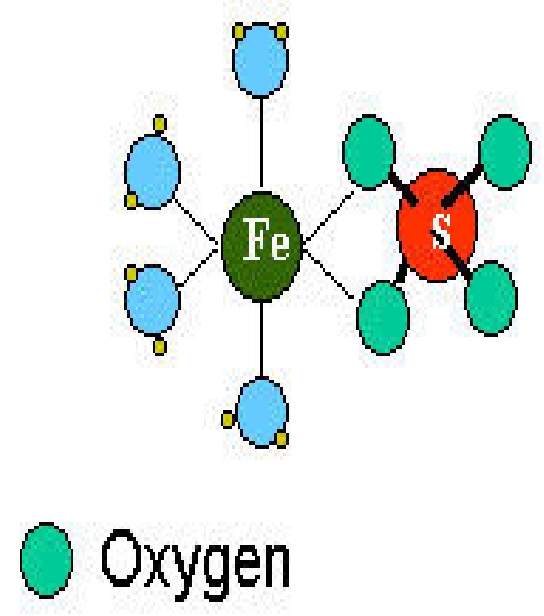

Figure 2.2 Formations of inner sphere and outer sphere surface complexes between sulfate and iron hydroxide (Princeton, 2006)

(Inskeep, 1989). Specific adsorption results in a stronger bond than non-specific and accordingly the sulfate is not easily desorbed when inner sphere complexes are formed. If 
the sulfate is retained through covalent bonding, adsorption may be essentially unlimited, and desorption may be delayed long after decreases in sulfate deposition (Charlet et al., 1993).

Much controversy has existed regarding the dominant mechanism of sulfate adsorption. Deciphering the adsorption mechanism is important for predicting the adsorption capacity of a soil and the rate of sulfate desorption. Hingston et al. (1972) grouped sulfate adsorbed on metal hydroxides under specific adsorption as $\mathrm{HSO}_{4}{ }^{-}$. Likewise, Neary et al. (1987) sited specific adsorption as the dominant mechanism for sulfate adsorption. Rajan (1977) proposed that sulfate formed a ring structure when adsorbed to aluminum hydroxides. Curtin and Syers (1990) indicated that sulfate might not be chemisorbed as commonly supposed. They used the term low affinity specific adsorption, in which the sorbed anion does not become chemically coordinated with the surface metal atoms. Zhang and Sparks (1990) agreed that outer sphere complexation or electrostatic attractions predominate with sulfate adsorption. Perrson and Lövgren (1996) used both potentiometric and spectroscopic studies and established that the dominant mechanism for sulfate adsorption is through outer sphere complexation. This agrees with the work done by He et al. (1997) who also concluded that sulfate is adsorbed by forming outer sphere complexes.

Sulfate adsorption is a concentration dependent process; it is influenced by the concentration of sulfate in the incoming solution relative to the concentration at which the soil had previously equilibrated. Sulfate adsorption increases as the sulfate concentration increases. The affinity for adsorption increases but at a decreasing rate, until a maximum adsorption level is reached. If the concentration of sulfate input decreases then the soil may begin releasing or desorbing sulfate until a new equilibrium concentration is achieved. Over long periods of time, some of the adsorbed, insoluble sulfate would probably become available to leaching by precipitation if the solution sulfate concentrations were reduced (Johnson et al., 1981). The concentration-dependent relationship between soil solution sulfate and adsorbed sulfate will result in a front moving downward through the soil (Reuss and Johnson, 1986). Release of sulfate varies with soil affinity for sulfate where highly retentive soils exhibit low reversibility and less retentive soils show high reversibility (Singh, 1984). Adsorption is generally found to be 
only partially reversible, commonly referred to as hysteresis, where the desorption isotherm lies above the adsorption isotherm. Any process that increases sulfate retention in the soil profile or delays sulfate release will reduce cation leaching.

The soil properties that have the most influence on the sulfate adsorption capacity of a soil are parent material, organic carbon, iron and aluminum oxy-hydroxides, clay content, the presence of competing anions, the soil surface charge, and the ionic strength and $\mathrm{pH}$ of the soil solution. Aluminum and iron are primarily responsible for sulfate adsorption in soil, whether they are present as free hydrous oxides or as constituents of clay minerals (Rajan, 1978; Black and Waring, 1979). Sulfate adsorption is higher in soils developed from iron and aluminum oxy-hydroxides. Iron and aluminum oxides increase sulfate adsorption by providing surfaces for adsorption to occur. Because the amount of sulfate adsorption is proportional to the amount of iron or aluminum oxides in soils, greater adsorption is expected in soils that have a larger quantity of sesquioxides (He et al., 1997).

Ionic strength will also influence sulfate adsorption. Changing the background electrolyte concentration influences the adsorption of ions at the surface interface by affecting the double-layer thickness resulting in the competition between the electrolyte ions and adsorbing ions for available surface sites. For sulfate adsorption, the electrolyte ions compete with sulfate ions and thus sulfate adsorption decreases with increasing ionic strength (He et al., 1997). The ionic strengths of forest soil solutions can vary by more than ten times (Table 2.1 ). Thus the sulfate adsorption capacity can vary greatly among Table 2.1 Ionic strength of a few selected surface soil solutions (Harter and Naidu, 2001)

\begin{tabular}{ll}
\hline Great Group & Ionic Strength \\
\hline Hapludult & 1.02 \\
Paleudult & 0.52 \\
Rhodudult & 6.42 \\
Hapludult & 1.93 \\
Xerochrept & 8.35 \\
Dystropept & 1.06 \\
Paleustult & 0.20 \\
Dystrandept & 9.21 \\
\hline
\end{tabular}

different soils. Ionic strength may also affect sulfate adsorption by increasing the proton 
surface charge (Charlet, 1993).

Soil solution $\mathrm{pH}$ represents a key variable controlling sulfate sorption by determining the polarity and density of the surface charge of sesquioxides. As the $\mathrm{pH}$ of the soil solution decreases the soil acquires a positive charge on variable charged particles. Variable charge occurs on soil components such as organic matter, oxides, hydroxides, oxyhydroxides, and edges of phyllosilicates (Sparks, 1995). The charge arises from the protonation and deprotonation of functional groups at the soil surfaces. In acidic conditions excess adsorbed hydrogen ions result in a net positive charge at the hydroxyl functional groups (Evangelou, 1998). Because of this positive charge, soils with a low $\mathrm{pH}$ have a higher capacity for sulfate adsorption. This increase in adsorption capacity is due to the increase in the electrostatic potential of the sorption plane with decreasing $\mathrm{pH}$. At high $\mathrm{pH}$, surfaces become negatively charged because of $\mathrm{H}^{+}$ deprotonation or $\mathrm{OH}^{-}$adsorption, and sulfate may be repelled. Surface charge for variable charged minerals will fluctuate with electrolyte concentration, solvent characteristics, temperature, and the ionic makeup of the soil solution (Sparks, 1995). The magnitude of the surface charge density on amphoteric surfaces is a function of $\mathrm{pH}$ and ionic strength in the soil solution that encompasses both the effects of the background electrolyte concentration and the ionic composition of the soil solution (Qafoku and Sumner, 2002). Thus, the quantity of variable surface charge will depend on the ionic strength of the soil solution and the solution $\mathrm{pH}$ (Figure 2.3).

Organic matter will also influence sulfate adsorption. There is still some debate as to whether organic matter has a positive or negative influence on sulfate adsorption. Autry and Fitzgerald (1993) suggested that incorporation of sulfate into organic matter might be an important mechanism for long-term sulfate retention. Alternatively, organic acids containing carboxylic acid or phenolic functional groups can bind to oxide surfaces thereby reducing the number of surface sites available for adsorption of inorganic anions (Inskeep, 1989). Soils with high accumulations of organic carbon have lower sulfate adsorption capacities because dissolved organic carbon competes with sulfate for adsorption sites (Johnson and Todd, 1983). Leaching of sulfate can occur if the positively charged sites of iron and aluminum hydrous oxides are blocked by organic ligands (Martinez et al., 1998). 


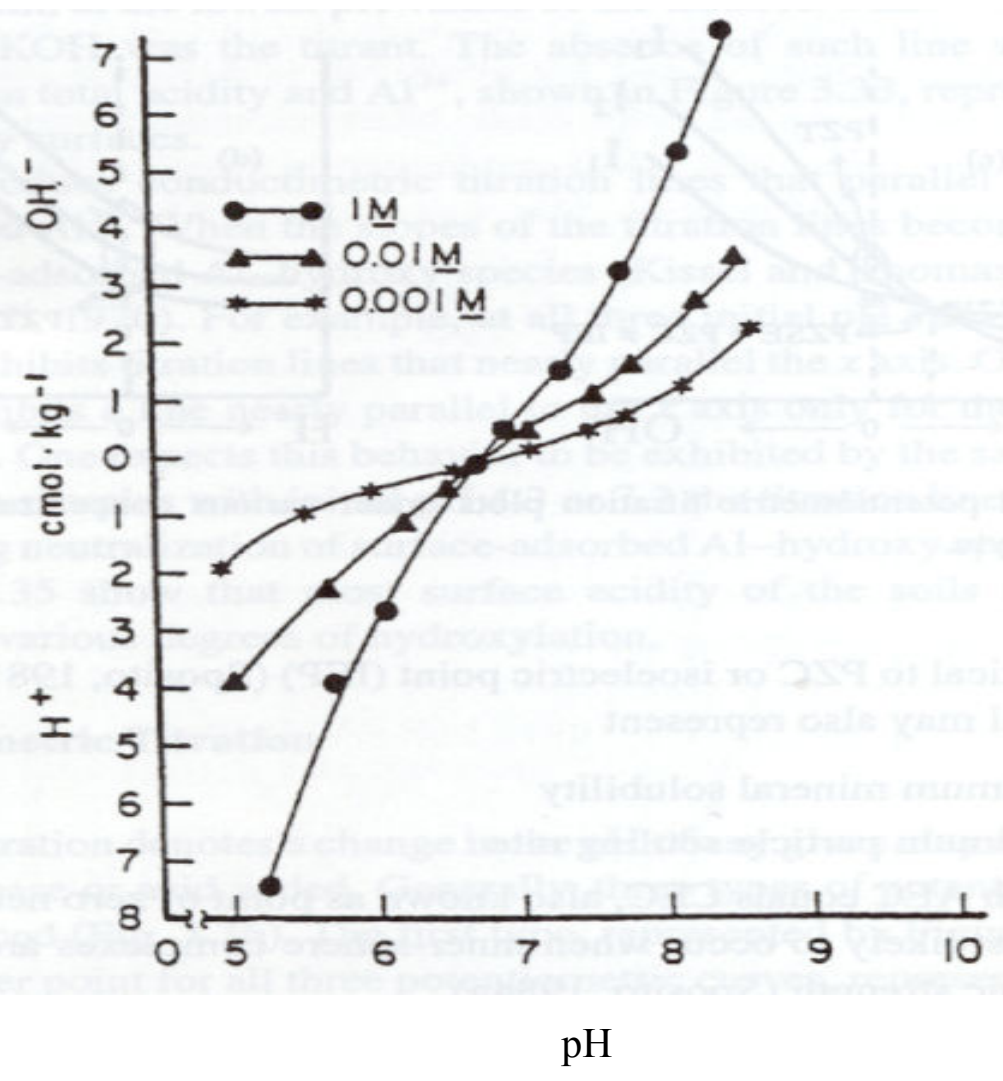

Figure 2.3 Surface charge versus $\mathrm{pH}$ and ionic strength (Evangelou, 1998)

Inorganic anions may also compete with sulfate for exchange sites. Generally the surface will show a higher affinity for the anion with the greater charge density. Therefore sulfate is generally adsorbed to soil particles more than nitrate (Rose, 1998) and less than phosphate (Gillman, 1974). Neutralization of the positively charged sites by sulfate may create a dominantly negative charged surface that would repel anions that have a lower adsorption affinity than sulfate (Kinjo and Pratt, 1971). However, if an anion with the smaller charge density, such as nitrate, has significantly higher concentrations, there may be more of a competition for adsorption sites. The mineralogy of a soil also has a significant impact on the adsorption capacity of a soil.

The ability of clays to adsorb sulfate is dependent on the type of charge the clay particles possess. For example, with kaolinite, the variable charge is greater than the permanent charge; so positive charges around the edges of kaolinitic particles are generated by the protonation and deprotonation reactions of the hydroxyl groups on the surfaces of the colloids (Qafoku and Sumner, 2002). Soils with a low percentage of clay 
are sensitive to anion saturation. Johnson and Todd (1983) concluded that surface horizons adsorb little sulfate due to their high organic matter content and low clay and iron and aluminum oxide content. Sulfate adsorption capacities will vary with soil depth and soil horizon. Many researchers have noted higher soil sulfate in subsoils than in surface soils. Neary et al. (1987) found that the B horizon was still able to retain sulfate while the Ae horizon could not. Gillman (1974) attributed the increase in adsorption in lower horizons to a decrease in organic matter with depth exposing more positive sites for sulfate adsorption. Thus, the sulfate adsorption capacity of a soil will be dependent upon the concentration of the sulfate input, the concentration of competing anions, the quantity of surface charge on the soil particles, and the $\mathrm{pH}$ and ionic strength of the soil solution.

Forest soils in West Virginia have experienced high inputs of acid deposition causing increased acid anion concentrations to the point of saturation with respect to nitrate and sulfate (Adams et al., 2000; Schnably, 2003). Soils with nitrate and sulfate saturation experience greater nutrient depletion, causing reductions in soil fertility and forest productivity. Forest soils in this region are extremely vulnerable to nutrient deficiencies. Adams et al. (2000) observed calcium and magnesium leaching from the Fernow Experimental Forest at a rate of $10 \mathrm{~kg} / \mathrm{ha}$ and $6 \mathrm{~kg} / \mathrm{ha}$, respectively. Otter Creek Wilderness experiences high inputs of acid deposition (Figure 2.4). The National Atmospheric Deposition Program monitoring site in the nearby town of Parsons, WV recorded approximately $30 \mathrm{~kg} / \mathrm{ka}$ sulfate deposition for 2005 (Figure 2.5). The altitudes within the wilderness range from 1790 feet at the lowest point to 3920 feet at the highest point. Soil depth varies with elevation as thinner soils are encountered at higher elevations (Fuller et al., 1985), which may affect the sulfate adsorption capacity. This area is of special concern because management options are limited due to its wilderness designation. The dominant geology type underlying the soil in Otter Creek is the sandstone of the Pottsville formation. The Pottsville sandstone is extremely weather resistant and produces acidic soils with a limited ability to buffer acidic inputs (Adams et al., 2000).

The capacity of these soils to adsorb sulfate is an important factor when assessing the impact of acid deposition on forest ecosystems. The more strongly soil retains sulfate the more likely the effects of acidification can be delayed. Sulfate adsorption will 
counteract the effects of acid deposition by decreasing the transport of hydrogen and aluminum ions and aid in retaining nutrient-rich, alkali cations. If a soil has the capacity to retain sulfate there will be fewer mobile anions to move through the soil with the cations. For these reasons it is necessary to study the sulfate adsorption capacity of soils to gain a greater understanding of the effect of acid deposition on soil solution chemistry. Information about sulfate adsorption capacity is vital when assessing the potential for these soils to withstand chemical changes brought about by acid deposition. Investigating the sulfate adsorption capacity of a soil can give a better understanding of the soil's ability to offset the effects of acidic deposition. By measuring soil's ability to adsorb sulfate, we can evaluate how threatened these soils are to adverse effects from acid deposition.

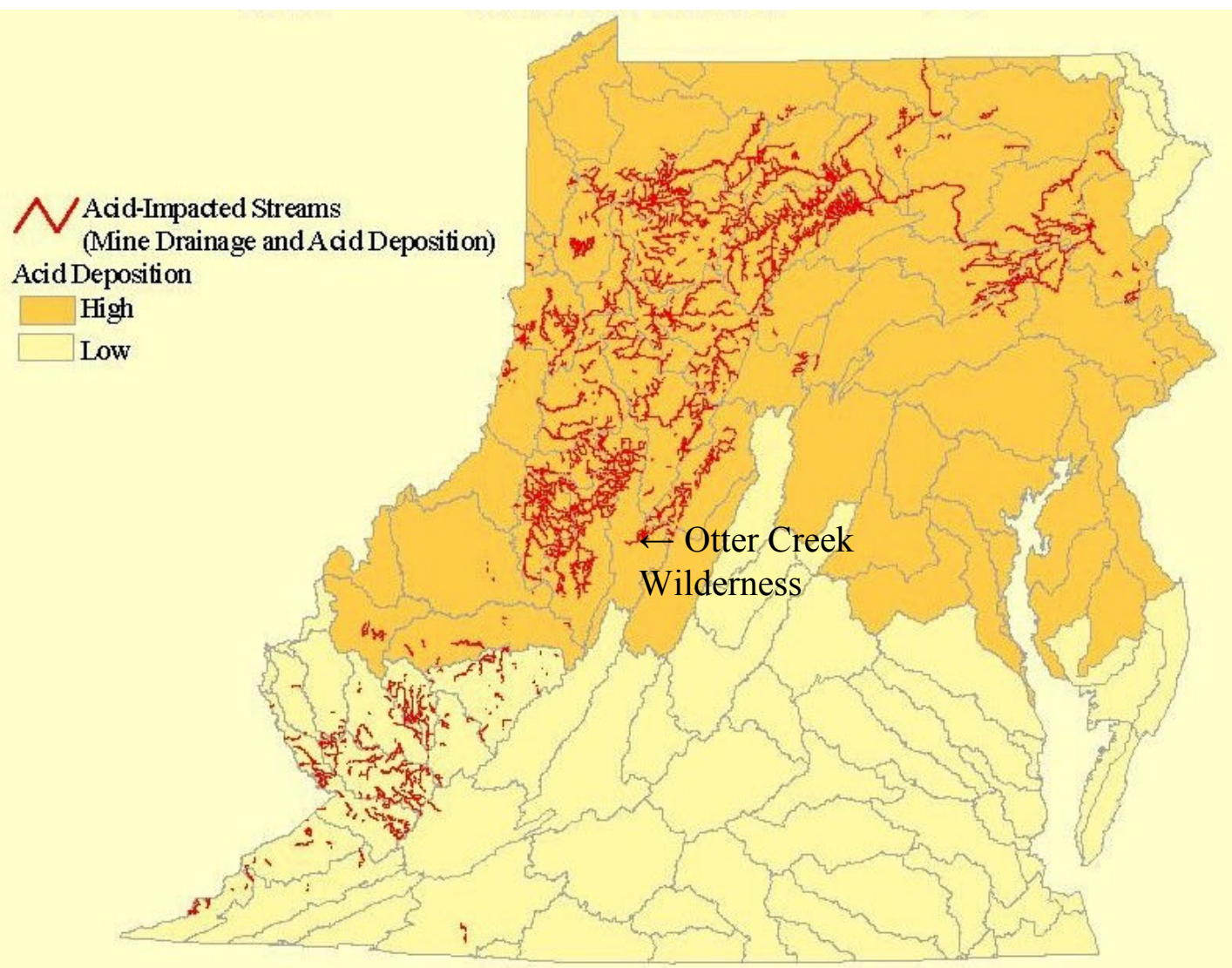

Figure 2.4 Distribution of acid deposition in West Virginia and the surrounding region (EPA, 2006) 


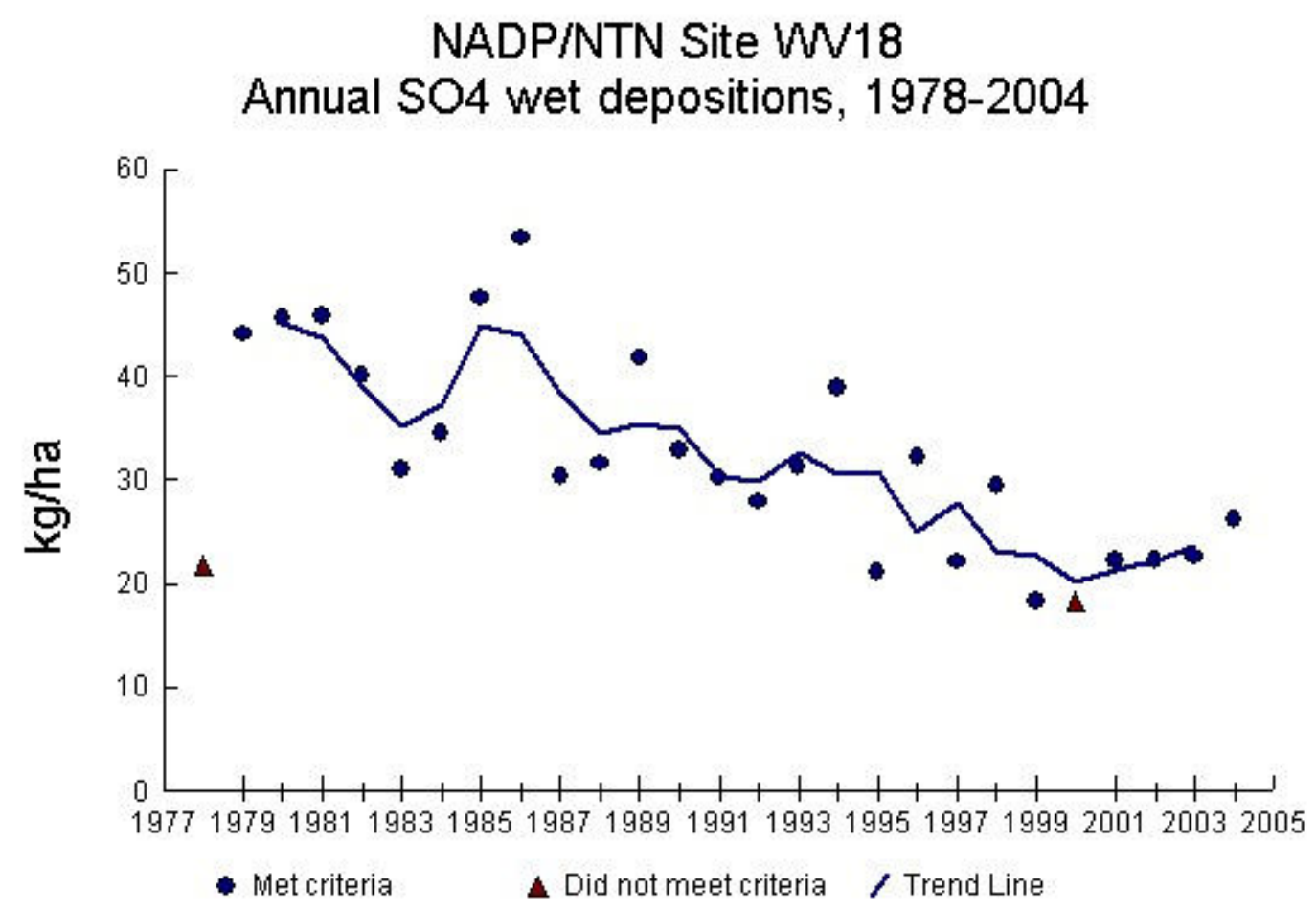

Figure 2.5 Trends in sulfate concentration in acid deposition over time at NADP site WV18 in Parsons, WV (NADP, 2005)

\section{Chapter 3.}

\section{Sulfate Adsorption Methods}

Acid deposition has caused tremendous stress to forest ecosystems through alterations in the soil chemistry. Increases in acidic inputs to forest soil can lead to increases in soil acidity and acid anion concentrations, increased mobilization of toxic aluminum and the depletion of cationic nutrients (Reuss and Johnson, 1986; Wolt, 1994). Studies have shown that the retention of sulfate in forest soil is a critical process regulating soil acidification (Reuss and Johnson, 1986). Soil sulfate adsorption capacity is considered an important parameter in assessing the sensitivity of soil to nutrient depletion and further acidification from acid deposition. By limiting the mobility of sulfate in the soil solution, the soil can experience decreased cation leaching. Retention of sulfate can also reduce the transport of aluminum (Wolt, 1994) and hydrogen ions (Persson and Lövgren, 1996). A soil continues to adsorb sulfate until a maximum adsorption capacity is reached at which point the soil is sulfate saturated. At sulfate saturation, any additional sulfate inputs will cause leaching to resume. Therefore it is 
important to measure the sulfate adsorption potentials and sulfate saturation points in forest soil.

Sulfate adsorption has been calculated by the single point method and the isotherm method. The single point method combines the soil with a single solution of known sulfate concentration. The sulfate adsorbed to the soil is then determined by the disappearance of sulfate from solution. With the adsorption isotherm method, a range of sulfate concentrations is added to the soil. The adsorbed sulfate at different concentrations is calculated as in the single point method. The concentration of sulfate adsorbed versus the equilibrium concentration is then plotted on a graph to obtain an isotherm. The number of analysis required to obtain sulfate adsorption isotherms for a large sample size is prohibitive (Johnson and Todd, 1983). The single point method has an advantage over the isotherm method in that it is not as tedious and time consuming as the isotherm method so it can be used for a large number of samples. However, the single point method is not as accurate as the isotherm method and often underestimates the adsorption potential of a soil. The single point method will only be able to show that a soil is still capable of adsorbing sulfate or is not sulfate saturated; it cannot portray the maximum amount of adsorbed sulfate. The most direct and effective way to determine sulfate adsorption capacity utilizes sulfate adsorption isotherms (Blume et al., 1990). Adsorption isotherms can provide information by which the properties of soils can be summarized in a few numbers, which can then be related to some other soil property. Isotherms allow comparisons to be made between horizons or pedons. Additionally, isotherms can help in understanding the nature of the adsorption process involved (Singh, 1984).

A recent study by Schnably (2003) characterized soils in the Otter Creek Wilderness Area. The research included an estimate of the extractable sulfate already present in the soil and the approximate sulfate adsorption capacity using the single point method. This information is a useful first step in assessing the sulfate saturation of these soils, however, it may not be an accurate prediction of the sulfate saturation point. In several of the soils the extractable sulfate was greater than the adsorbed sulfate leading one to question whether this is an accurate representation of the adsorption potential (Table 3.1). It is expected that extractable sulfate should be less than the adsorption 
Table 3.1 Extractable and adsorbed sulfate in the top B horizon (yellow indicates soils used in this study)

\begin{tabular}{cccc}
\hline Landscape Position & Horizon & Ex SO & Ads $\mathrm{SO}_{4}$ \\
\hline Sideslope & Argillic-1 & 13.6 & \\
Sideslope & Argillic-2 & 39.0 & 20.0 \\
Sideslope & Argillic-3 & 21.8 & 20.8 \\
Sideslope & Cambic-1 & 2.7 & 7.0 \\
Sideslope & Cambic-2 & 24.8 & 17.5 \\
Sideslope & Cambic-3 & 63.1 & 7.6 \\
Ridgetop-1 & & 12.5 & 22.0 \\
Ridgetop-2 & & 9.0 & 12.6 \\
Ridgetop-3 & & 4.3 & 6.9 \\
Ridgetop-4 & & 10.7 & -3.0 \\
Terrace-1 & & 2.0 & -5.6 \\
Terrace-2 & & 9.4 & -0.4 \\
Terrace-3 & & 48.8 & 8.5 \\
\hline
\end{tabular}

capacity if the soil is not sulfate saturated and equal to the adsorption capacity if it is saturated. If extractable sulfate is greater than the adsorbed sulfate then there is sulfate retention that is not being accounted for. In order to help explain these discrepancies, we re-examined the sulfate adsorption capacities for the Otter Creek Wilderness Area. The objectives of this research were to:

1. quantify sulfate adsorption capacity of Otter Creek soils using both single point and isotherm methods

2. compare sulfate adsorption potentials for single point and isotherm methods to extractable sulfate

3. identify an appropriate method for measuring adsorption potentials of forest soils in this region. 


\section{Materials and Methods}

Since the majority of sulfate adsorption occurs in the subsurface soil horizons (Gillman, 1974; Johnson and Todd, 1983; Neary, 1987), the four soils (Table 3.2) in this study were taken from the top B horizon of sites located in the Otter Creek Wilderness Area in the Monongahela National Forest, West Virginia. The soils were located on sideslopes with an argillic horizon (SSA1\&SSA2), a sideslope with a cambic horizon (SSC2), and a ridgetop (R1) (Figure 3.1). Schnably (2003) performed a series of laboratory experiments on these soils to determine texture (Indorante et al., 1990), $\mathrm{pH}$ (Method 8C1, 8C1e, Soil Survey Staff, 1996), soil organic carbon (Jenkins, 2001), extractable aluminum (Method 6G, Soil Survey Staff, 1996), acidity (Method 6H, Soil Survey Staff, 1996) calcium, magnesium, sodium and potassium (Method 5A8, Soil Survey Staff, 1996), phosphorus (Method 6S, Soil Survey Staff, 1996) cation exchange capacity (Method 5A8b, Soil Survey Staff, 1996), clay mineralogy (Table 3.3) (Method 7A1b, Soil Survey Staff, 1996), and extractable and adsorbed sulfate (MacDonald and Hart Jr., 1990). A detailed description of the study area, soil properties, and laboratory procedures is described by Schnably (2003).

Because iron and aluminum oxides may increase sulfate adsorption, their presence in the soil was determined using the ammonium oxalate dark treatment (AOD) (Jackson et al., 1986). Fifty milliliters of ammonium oxalate (0.2 M) adjusted to $\mathrm{pH} 3.0$ was added to 0.25 grams of oven-dried soil in pre-weighted $50 \mathrm{ml}$ centrifuge tubes wrapped in aluminum foil to eliminate light. The tubes were shaken for two hours and centrifuged. The supernatants were removed and analyzed for iron and aluminum. The

Table 3.2 Selected properties of the soils used in this study (Schnably, 2003)

\begin{tabular}{ccccccccc}
\hline $\begin{array}{c}\text { Landscape } \\
\text { Position }\end{array}$ & Horizon & Classification & $\% \mathrm{C}$ & $\mathrm{pH}$ & $\mathrm{CEC}$ & $\begin{array}{c}\mathrm{Ex} \\
\text { Acidity }\end{array}$ & $\begin{array}{c}\mathrm{Ex} \\
\mathrm{Al}\end{array}$ & $\begin{array}{c}\mathrm{Ex} \\
\mathrm{Ca}\end{array}$ \\
\hline Sideslope & Argillic-1 & $\begin{array}{c}\text { Ultic } \\
\text { Hapludalfs } \\
\text { Typic }\end{array}$ & 0.6 & 4.6 & 11.9 & 11.3 & 4.1 & 1.3 \\
Sideslope & Argillic-2 & $\begin{array}{c}\text { Hapludults } \\
\text { Humic }\end{array}$ & 0.4 & 4.4 & 10.4 & 11.2 & 4.2 & 0.2 \\
Sideslope & Cambic & $\begin{array}{c}\text { Dystrudepts } \\
\text { Aeric }\end{array}$ & 4.3 & 14.3 & 16.2 & 6.1 & 0.1 \\
Ridgetop & Cambic & $\begin{array}{c}\text { Fragiaquepts } \\
\text { Cagle }\end{array}$ & 4.4 & 17.4 & 18.2 & 4.3 & 0.3 \\
\hline
\end{tabular}




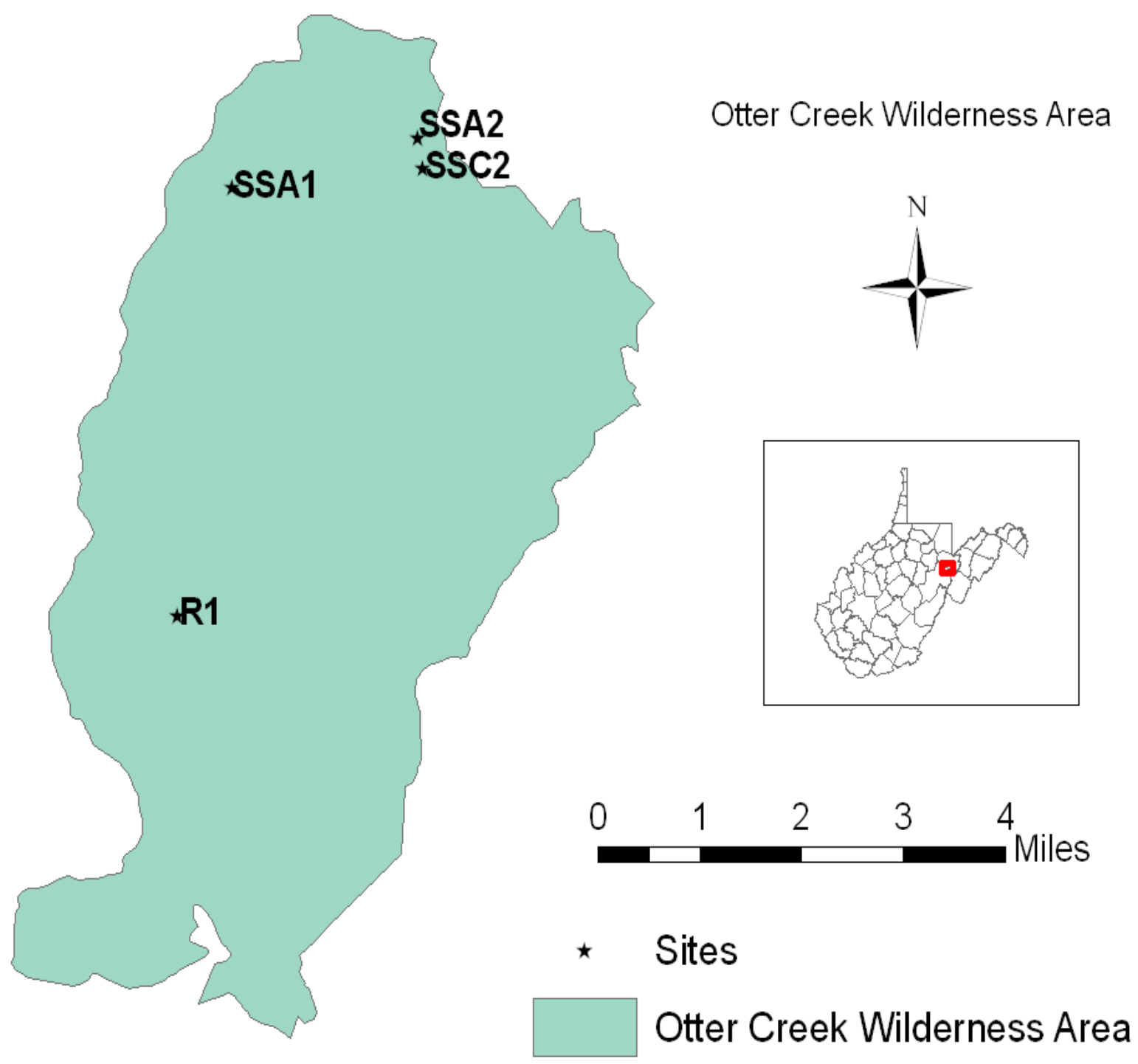

Figure 3.1 Site locations in Otter Creek Wilderness Area

Table 3.3 Clay mineralogy for each pedon used in this study (Schnably, 2003)

\begin{tabular}{|c|c|c|c|c|c|c|}
\hline $\begin{array}{c}\text { Landscape } \\
\text { Position }\end{array}$ & Horizon & Vermiculite & Kaolinite & Illite & Lepid & Quartz \\
\hline Sideslope & Argillic-1 & 51 & 21 & 8 & A & 20 \\
\hline Sideslope & Argillic-2 & 35 & 26 & 14 & A & 25 \\
\hline Sideslope & Cambic-2 & 41 & 23 & 10 & A & 27 \\
\hline Ridgetop & Cambic & A & 41 & 18 & 18 & 23 \\
\hline
\end{tabular}

A indicates absent or present in trace amounts. 
residues in the tubes were washed three times with $0.5 \mathrm{M}\left(\mathrm{NH}_{4}\right)_{2} \mathrm{CO}_{3}$ and once with distilled water to remove remaining dissolution treatment chemicals. The tubes were dried overnight in an oven at $110^{\circ} \mathrm{C}$ to volatilize excess $\left(\mathrm{NH}_{4}\right)_{2} \mathrm{CO}_{3}$ as $\mathrm{NH}_{3}, \mathrm{CO}_{2}$, and $\mathrm{H}_{2} \mathrm{O}$; then cooled in a desiccator and weighed to determine the amount of material dissolved by the AOD treatment.

Native sulfate content of the samples was determined with the method used by Schnably (2003), extraction with $0.008 \mathrm{M} \mathrm{Ca}\left(\mathrm{H}_{2} \mathrm{PO}_{4}\right)_{2}$ (Table 3.4). Twenty-five milliliters of the extracting solution were added to 10 grams of soil. The suspensions were placed on a reciprocating shaker for 1 hour, centrifuged for 10 minutes or until the supernatant was clear, and filtered through a $0.45 \mu \mathrm{m}$ syringe filter. Additional sulfate extractions were performed using the EPA's method for studying soils affected by acid deposition (Blume et al., 1990). This method accounts for both soluble and insoluble sulfate in the soil. Soluble sulfate was determined by extracting sulfate with deionized water. Forty milliliters of distilled deionized water were added to 2 grams of soil in a 50$\mathrm{mL}$ centrifuge tube. The suspensions were shaken for 1 hour, centrifuged, and filtered as in the previous method. Insoluble or adsorbed sulfate plus soluble sulfate was extracted with 4 consecutive additions of $0.008 \mathrm{M} \mathrm{Ca}\left(\mathrm{H}_{2} \mathrm{PO}_{4}\right)_{2}$. After each addition the suspensions were shaken, and centrifuged. The supernatants were combined in a 50-ml volumetric flask, brought to volume with the extractant solution and filtered. Initial adsorbed or insoluble sulfate was calculated by subtracting $\mathrm{H}_{2} \mathrm{O}$-extractable sulfate from $\mathrm{CaH}_{2} \mathrm{PO}_{4}$ extractable sulfate.

Sulfate was then added to the soil to determine whether these soils could adsorb additional sulfate inputs. Using the single point method, 5.0 grams of soil were equilibrated with $25 \mathrm{~mL}$ of a $0.01 \mathrm{M} \mathrm{CaCl}_{2}$ solution containing $0.312 \mathrm{mmol} \mathrm{SO}_{4}$ added as $\mathrm{Na}_{2} \mathrm{SO}_{4}$ (MacDonald and Hart, 1990). The suspensions were placed on a reciprocating shaker for 1 hour, centrifuged for 10 minutes or until the supernatant was clear and filtered through a $0.45 \mu \mathrm{m}$ syringe filter. With the isotherm method, $25 \mathrm{~mL}$ of $0-5 \mathrm{mM}$ $\mathrm{SO}_{4}$ as $\mathrm{MgSO}_{4}$ was added to 5.0 grams of soil (Blume et al., 1990). Again, the suspensions were shaken, centrifuged, and filterered. The $\mathrm{pH}$ was measured on the 0 and $5 \mathrm{mM}$ samples before centrifuging with an Accumet model $15 \mathrm{pH}$ meter to get a range of $\mathrm{pH}$ values for the isotherm method. A proposed double point method for sulfate 
adsorption was performed using the same procedure as the isotherm method except only two of the original sulfate concentrations were used, 4 and $5 \mathrm{mM} \mathrm{SO}_{4}$ as $\mathrm{MgSO}_{4}$.

Table 3.4 Descriptions of methods used in this study

\begin{tabular}{|c|c|c|c|}
\hline Method & $\begin{array}{c}\text { Extractant } \\
\text { concentration }\end{array}$ & $\mathrm{SO}_{4}{ }^{2-}$ concentration & Reference \\
\hline $\begin{array}{l}\text { Native single extractable } \\
\qquad \mathrm{SO}_{4}{ }^{2-}\end{array}$ & $0.008 \mathrm{M} \mathrm{Ca}\left(\mathrm{H}_{2} \mathrm{PO}_{4}\right)_{2}$ & & $\begin{array}{l}\text { Schnably } \\
(2003)\end{array}$ \\
\hline $\begin{array}{l}\text { Native extractable water } \\
\text { soluble } \mathrm{SO}_{4}{ }^{2-}\end{array}$ & $\begin{array}{l}\text { Distilled Deionized } \\
\text { water }\end{array}$ & & $\begin{array}{l}\text { Blume et al } \\
\qquad(1990)\end{array}$ \\
\hline $\begin{array}{c}\text { Native multiple extractable } \\
\text { adsorbed } \mathrm{SO}_{4}{ }^{2-}\end{array}$ & $0.008 \mathrm{M} \mathrm{Ca}\left(\mathrm{H}_{2} \mathrm{PO}_{4}\right)_{2}$ & & $\begin{array}{l}\text { Blume et al } \\
\text { (1990) }\end{array}$ \\
\hline Single point $\mathrm{SO}_{4}{ }^{2-}$ adsorption & & $\begin{array}{c}0.01 \mathrm{M} \mathrm{CaCl}_{2} \text { with } \\
0.312 \mathrm{mM} \mathrm{SO}_{4} \text { as } \\
\mathrm{Na}_{2} \mathrm{SO}_{4}\end{array}$ & $\begin{array}{l}\text { Schnably } \\
(2003)\end{array}$ \\
\hline 2-point $\mathrm{SO}_{4}{ }^{2-}$ adsorption & & $\begin{array}{c}\text { 0-5 } \mathrm{mM} \mathrm{SO}_{4} \text { as } \\
\mathrm{MgSO}_{4}\end{array}$ & $\begin{array}{l}\text { Bryson } \\
(2006)\end{array}$ \\
\hline Isotherm $\mathrm{SO}_{4}{ }^{2-}$ adsorption & & $\begin{array}{l}4 \text { and } 5 \mathrm{mM} \text { as } \\
\mathrm{MgSO}_{4}\end{array}$ & $\begin{array}{l}\text { Blume et al } \\
\text { (1990) }\end{array}$ \\
\hline
\end{tabular}

All samples were analyzed on a Dionex Ion Chromatograph within 24 hours. Sulfate was detected using a Suppressed Conductivity (CD25) and an Anion SelfRegenerating Suppressor (ASRS ${ }^{\circledR}$ ULTRA II, 4mm) with the injection volume at $25 \mu \mathrm{L}$. The eluent used was $1.8 \mathrm{mM} \mathrm{Na}_{2} \mathrm{CO}_{3} / 1.7 \mathrm{mM} \mathrm{NaHCO} 3$ with a flow rate of $2.0 \mathrm{~mL} / \mathrm{min}$. Each experiment was replicated at least twice. Outliers were removed and averages were taken for each soil. Percent error was also performed for each experiment assuming the isotherm value as the maximum adsorption.

\section{Results and Discussion}

Sulfate retention by acidic soils is frequently associated with the adsorptive properties of Fe and Al oxides. Johnson and Todd (1983) found only crystalline iron to be significantly correlated with sulfate adsorption. Johnson et al. (1986) attributed more adsorbed sulfate in one soil to greater amorphous hydrous iron and aluminum oxides. While in the other soil, the hydrous iron and aluminum oxides were more crystalline; consequently, they weren't able to adsorb as much sulfate. Arbestain et al. (1999) concluded that total native sulfate correlated positively with the different aluminum and iron fractions studied. With the soils in this study, there does not appear be a correlation between the adsorption maximum and amount of iron and aluminum oxides (Table 3.5). 
Shanley (1992) also found that the relation between soil sulfate sorption properties and iron and aluminum fractions was weak. While there were not enough samples to provide conclusive evidence that iron and aluminum oxides are not responsible for sulfate adsoption in these soils, there may be other more dominant sulfate retention mechanisms at work in these soils such as positively charged clay edges.

Table 3.5 Presence of iron and aluminum oxides in soils

\begin{tabular}{cccccc}
\hline $\begin{array}{c}\text { Landscape } \\
\text { Position }\end{array}$ & Horizon & $\mathrm{SO}_{4} \mathrm{Ads}$ & Oxides & $\mathrm{Fe}_{\mathrm{o}}$ & $\mathrm{Al}_{\mathrm{o}}$ \\
\hline & & $\left(\mathrm{mg} \mathrm{kg}^{-1}\right)$ & $\%$ & $\left.-----\mathrm{g} \mathrm{kg}^{-1}\right)------$ \\
Sideslope & Argillic-1 & 209.2 & 5.2 & 1.2 & 3.2 \\
Sideslope & Argillic-2 & 229.6 & 4.3 & 1.3 & 2.6 \\
Sideslope & Cambic & 164.1 & 3.3 & 2.0 & 2.5 \\
Ridgetop & Cambic & 163.3 & 5.8 & 1.6 & 6.1 \\
\hline
\end{tabular}

Water extractable sulfate measures the weakly held or exchangeable sulfate present in the soil and phosphate extractable sulfate measures the strongly held or adsorbed sulfate, thus the water-soluble sulfate extraction method gives a good estimate of the amount of sulfate susceptible to leaching. The multiple sulfate extraction technique using $\mathrm{CaH}_{2} \mathrm{PO}_{4}$ obtained more extractable sulfate than the single sulfate extraction (Table 3.6). The multiple extractions give a more accurate representation of the amount of adsorbed sulfate already present in the soil. Adsorbed sulfate represents 68 to $84 \%$ of the

Table 3.6 Extractable sulfate using different methods.

\begin{tabular}{ccccc}
\hline $\begin{array}{c}\text { Landscape } \\
\text { Position }\end{array}$ & Horizon & $\begin{array}{c}\mathrm{H}_{2} \mathrm{O} \text { soluble } \\
\mathrm{SO}_{4}\end{array}$ & $\begin{array}{c}\text { Single } \mathrm{SO}_{4} \\
\text { extraction }\end{array}$ & $\begin{array}{c}\text { Multiple } \mathrm{SO}_{4} \\
\text { extraction }\end{array}$ \\
\hline Sideslope & Argillic-1 & 17.73 & 37.48 & 93.29 \\
Sideslope & Argillic-2 & 56.99 & 98.86 & 122.89 \\
Sideslope & Cambic & 32.04 & 73.56 & 116.51 \\
Ridgetop & Cambic & 19.03 & 39.26 & 91.96 \\
\hline
\end{tabular}

extractable sulfate in these soils. Fuller et al. (1985) found insoluble sulfate accounted for 82 to $90 \%$ of the extractable sulfate. Wolt (1981) measured the highest extractable sulfate concentrations in Argillic horizons ranging from 115 to $263 \mathrm{mg} \mathrm{kg}^{-1}$. Johnson and Todd (1983) recorded initial sulfate adsorbed at 10 to $15 \mathrm{mg} \mathrm{kg}^{-1}$ in Tennessee and 25 to $70 \mathrm{mg}$ $\mathrm{kg}^{-1}$ in North Carolina. Shanley (1992) found that sulfate recovery with two water 
extractions was consistently higher than using only one water extraction. However, Neary et al. (1987) concluded that sulfate may be leached continuously with water but yield decreased with each successive extraction. Likewise, it is commonly found that more than one phosphate extraction is needed to recover all of the strongly held sulfate (Shanley, 1992).

Both the single point method and the isotherm method indicate that these soils are still capable of retaining sulfate. The isotherm method demonstrates a larger adsorption capacity than the single point method (Table 3.7). Discrepancies in the data arise when comparing the single point method to the extractable sulfate. The extractable sulfate is greater than the adsorbed sulfate for all of the soils with the multiple extraction procedure, and only SSA1 is less than the adsorbed sulfate for the single procedure (Table 3.7). Whereas, with the isotherm method, the extractable sulfate is less than the adsorbed sulfate for all the samples, as expected. The single point method is only able to establish that the soil is still capable of retaining sulfate, it cannot determine the maximum amount of sulfate that a soil is able to adsorb, and it misses the critical transition zone where sulfate saturation begins. With the isotherm method, the maximum amount of sulfate adsorbed and the sulfate saturation point is known (Figure 11). The single point method using $0.312 \mathrm{mmol} \mathrm{SO}_{4}$ underestimates the $\mathrm{SO}_{4}$ adsorption capacity of

Table 3.7 Single point and isotherm estimates of sulfate adsorption capacity

\begin{tabular}{ccccccc}
\hline $\begin{array}{c}\text { Landscape } \\
\text { Position }\end{array}$ & Horizon & $\mathrm{pH}$ & $\begin{array}{c}\text { Single } \\
\mathrm{Ex} \mathrm{SO}_{4}\end{array}$ & $\begin{array}{c}\text { Multiple } \\
\mathrm{Ex} \mathrm{SO}_{4}\end{array}$ & $\begin{array}{c}\text { Single Point } \\
\mathrm{Ads} \mathrm{SO}_{4}\end{array}$ & $\begin{array}{c}\text { Isotherm } \\
\text { Ads SO }_{4}\end{array}$ \\
\hline & & & & \multicolumn{3}{c}{$\left(\mathrm{mg} \mathrm{kg}^{-1}\right)$} \\
Sideslope & Argillic-1 & $4.31-5.03$ & 37.48 & 93.3 & 39.8 & 209.2 \\
Sideslope & Argillic-2 & $4.21-4.74$ & 98.86 & 122.9 & 39.0 & 229.6 \\
Sideslope & Cambic-2 & $4.22-4.50$ & 73.56 & 116.5 & 22.3 & 164.1 \\
Ridgetop & Cambic & $3.85-4.29$ & 39.26 & 92.0 & 25.7 & 163.3 \\
\hline
\end{tabular}

this soil. This concentration may be more accurate for soils with a lower adsorption capacity. It was originally proposed by MacDonald and Hart Jr. (1990) to approximate 


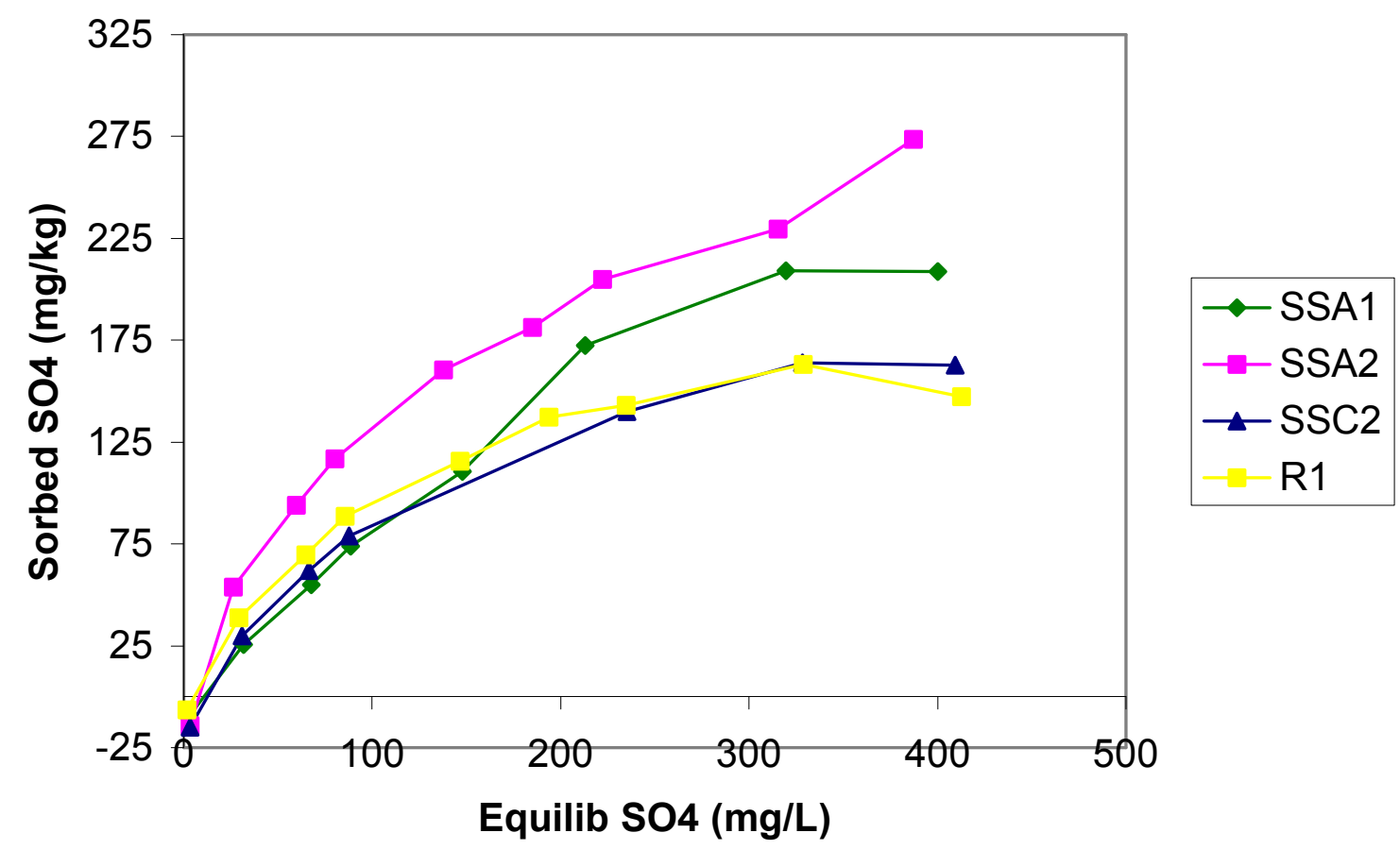

Figure 3.2. Adsorption Isotherms for all four soils. Different colors depict different soils.

the soil solution concentrations of sulfate in their soils. When using the single point method, the initial $\mathrm{SO}_{4}$ concentration should be increased for soils in this region (Table 3.8). The two point method was able to accurately predict the sulfate adsorption potential

Table 3.8 Percent error for single point and two point at different sulfate concentrations (negative sign denotes underestimation)

\begin{tabular}{cccccc}
\hline $\begin{array}{c}\text { Landscape } \\
\text { Position }\end{array}$ & Horizon & $\begin{array}{c}\text { Single Point } \\
0.312 \mathrm{mM}\end{array}$ & $\begin{array}{c}\text { Single Point } \\
3.0 \mathrm{mM}\end{array}$ & $\begin{array}{c}\text { Single Point } \\
4.0 \mathrm{mM}\end{array}$ & $\begin{array}{c}\text { 2 Point } \\
\text { 4.0 \& 5.0 mM }\end{array}$ \\
\hline & & \multicolumn{5}{c}{ - } \\
Sideslope & Argillic-1 & -81.0 & -17.6 & -0.67 & 0.60 \\
Sideslope & Argillic-2 & -83.0 & -10.7 & -0.74 & -0.75 \\
Sideslope & Cambic-2 & -86.4 & -14.7 & 0.06 & 0.06 \\
Ridgetop & Cambic & -84.3 & -12.5 & -0.37 & -0.93 \\
\hline
\end{tabular}


of these soils. There was no significant difference between the maximum adsorption with the two point method and the isotherm method when comparing the confidence intervals for the maximum adsorption capacities at the 0.05 significance level.

SSA2 appeared to show more precipitation than adsorption at $5 \mathrm{mM}$, as noted by a sharp increase in the isotherm line. Maximum adsorption for SSC2 is assumed to be somewhere between 4 and $5 \mathrm{mM}$ where the isotherm line appears to be leveling off before apparent oversaturation occurs. The control of solution sulfate concentrations by precipitation of jurbanite alunite, or basaluminite has been suggested in many studies. It is generally difficult to distinguish between adsorption and precipitation reactions in macroscopic studies because only a small amount of precipitate needs to be present in order to control the solubility of sulfate and it is often not feasible to directly determine the presence of these precipitates (Charlet, 1993). Therefore precipitation reactions are examined by comparing the ion activities in solution with the solid's equilibrium constant. Charlet et al. (1993) found that the ion activity product for aluminum, hydroxide, and sulfate at 17.7 closely resembled the $p \mathrm{~K}_{\mathrm{sp}}$ of jurbanite at 17.8. However, in their study since no apparent stability with jurbanite occurred, they rejected the hypothesis that sulfate was controlled by jurbanite precipitation. A similar conclusion was drawn in this study with respect to jurbanite, and gypsum. The solubility constant for gypsum and basaluminite were compared to the ion activity product assuming that all exchangeable calcium and aluminum were available to react with the sulfate in the equilibrium solution. Because the ion activity product was less than the solubility constant, it can be assumed that no precipitation of gypsum or basaluminite occurred. To establish whether alunite had precipitated, aluminum was assumed to be in equlibrium with gibbsite. As the concentration of potassium and sulfate increase, alunite becomes the most stable precipitate to form at the $\mathrm{pH}$ range of these soils, so alunite may be responsible for the sharp increase on the isotherm line for SSA2 at the highest sulfate concentration (Figure 3.4). $\mathrm{R} 1$ and $\mathrm{SSC} 2$ have the lowest $\mathrm{SO}_{4}$ retention capacities, while SSA1 and SSA2 have the greatest adsorption potentials. These observations agree with previous research where higher adsorption capacities were observed in highly weathered soils with high clay contents (Chao et al., 1962). Likewise, Johnson and Todd (1983) found percent clay significantly correlated with adsorbed sulfate. The observation that the 


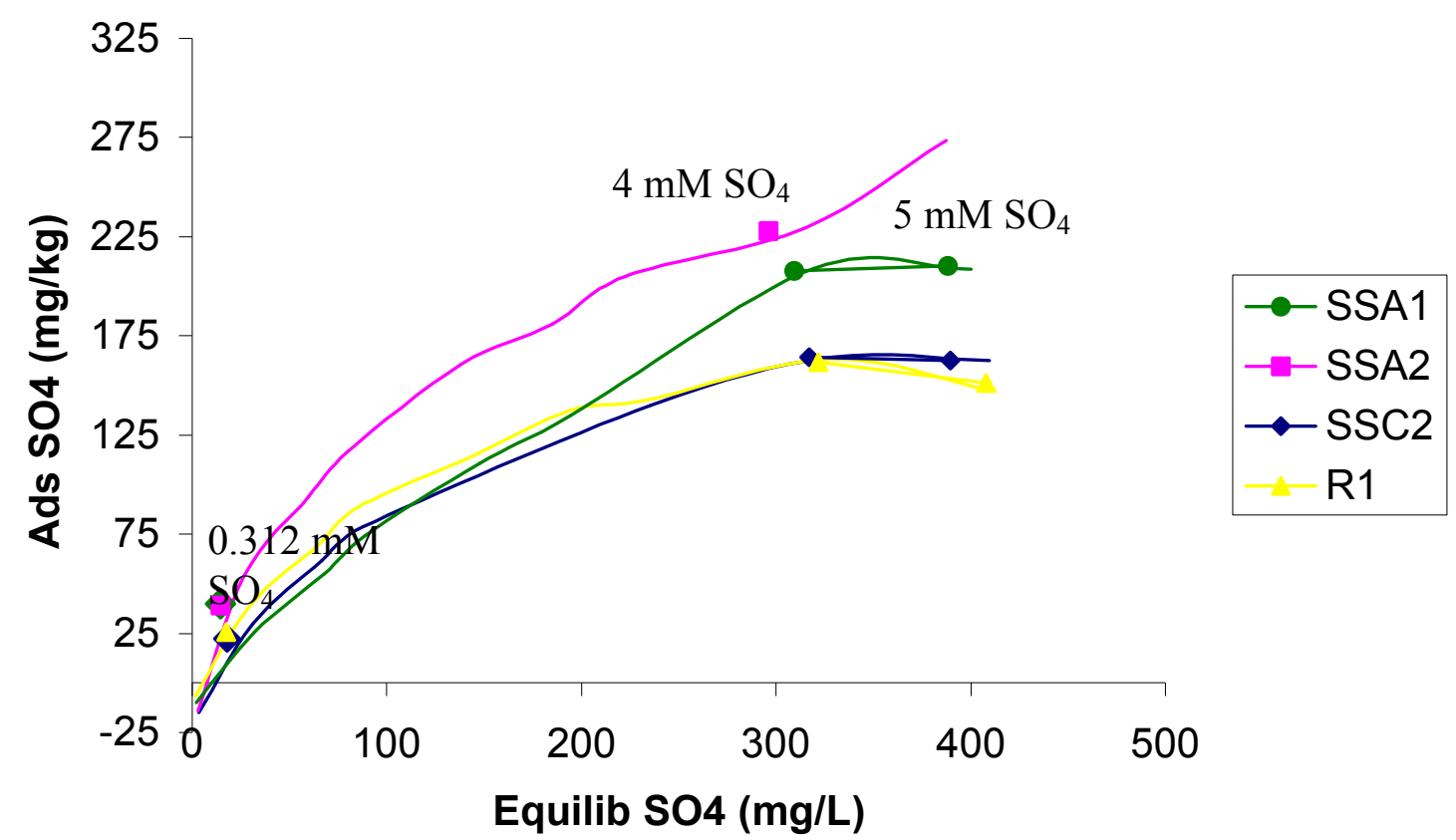

Figure 3.3 The relationship between $\mathrm{SO}_{4}$ adsorption isotherm lines, the 2-point method, and the single point method. Different colors represent different soils. Single point method underestimates adsorption potential.

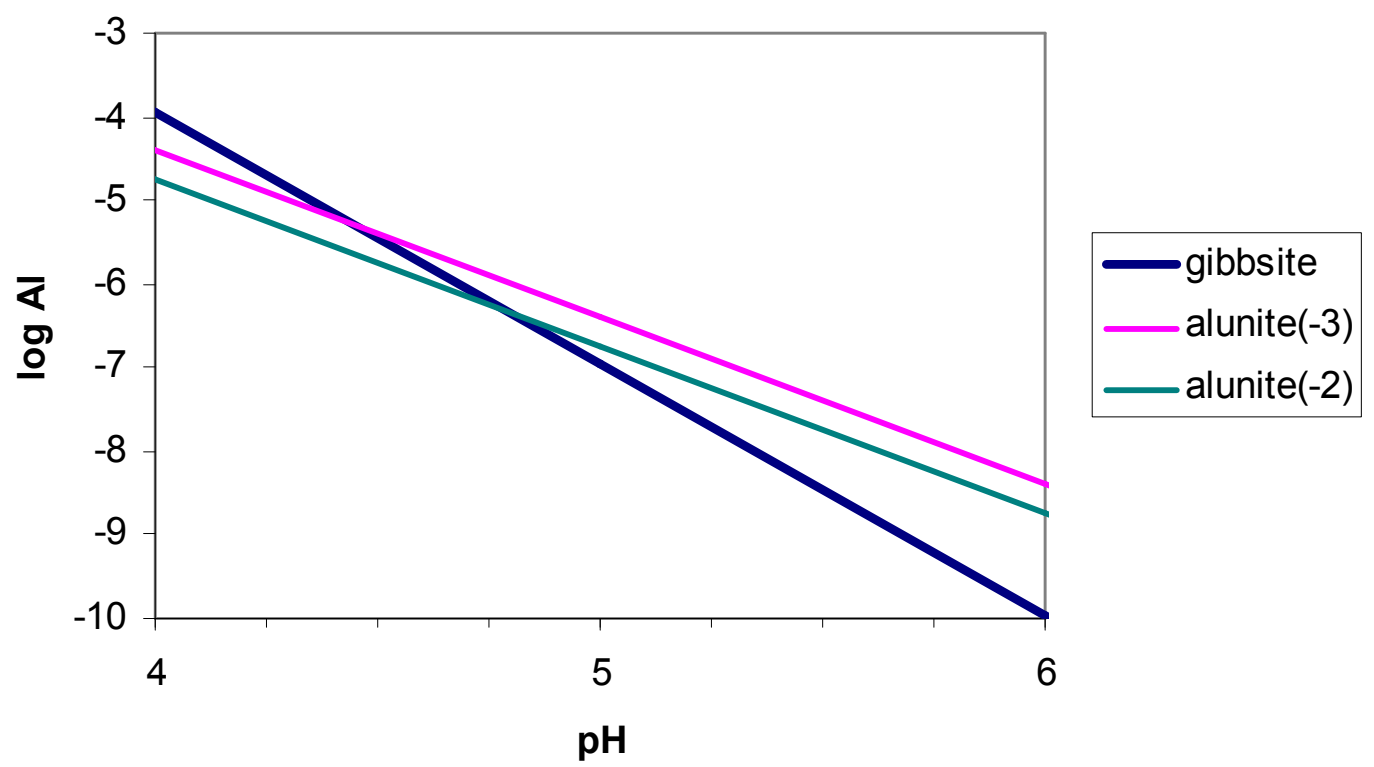

Figure 3.4. Gibbsite-alunite solubility relationships as a function of $\mathrm{pH}$. Alunite function assumes $\log \mathrm{SO}_{4}{ }^{2-}=-2.38$ and $\log \mathrm{K}^{+}=-3$ or -2 . Equilibrium constants from Lindsay 1979. 
soils with high clay content have higher adsorption capacities supports the belief that clay is playing a role in sulfate adsorption but there is not enough conclusive evidence to prove this theory.

MacDonald and Hart (1990) used a concentration of $0.312 \mathrm{mM}$ sulfate with the single point method. This concentration was chosen to approximate the soil-solution concentrations of sulfate in their soils and to minimize discrepancies between air-dry and field-moist samples. Johnson and Todd (1983) used $2.34 \mathrm{mM}$ sulfate as index for sulfate adsorption. Curtin and Syers (1990) obtained a single point index of sulfate adsorption with $7.8 \mathrm{mmol} \mathrm{SO}_{4}-\mathrm{S} \mathrm{kg}^{-1}$ and found that only five of forty-eight soils adsorbed more than $1 \mathrm{mmol} \mathrm{SO}_{4}-\mathrm{S} \mathrm{kg}^{-1}$ with a maximum of $2.3 \mathrm{mmol}$. One must be cautious when choosing an appropriate concentration for the single point method; too low of a concentration will cause an underestimation of adsorption potential, however too high a concentration may lead to more precipitation than adsorption. To alleviate these concerns a two-point method was developed to study sulfate adsorption. The two-point method is not as time consuming as the isotherm method yet it is more accurate than the single point method. The two-point method may allow one to detect whether precipitation is occurring by noting if there is a large increase in adsorption when the soil appears to be reaching saturation. This observation is important because it allows one to detect oversaturation so that the adsorption capacity is not overestimated.

Singh (1984) used the isotherm method with concentration of sulfate ranging from 0.1 to $8.3 \mathrm{mM}$ and found that none of the soils reached an adsorption maximum at the concentration range tested. The soils used in a sulfate adsorption study by Johnson et al. (1979) also did not reach an adsorption maximum at the concentration range of 0 to $9.5 \mathrm{mM} \mathrm{SO}_{4}{ }^{2-}$. Similarly, Kaiser and Kaupenjohann (1998) concluded that none of the horizons reached its retention capacity within the range of 0 to $5 \mathrm{mM} \mathrm{SO}_{4}$. Neary et al. (1987) determined that the B horizons were able to adsorb $1.5-2.5 \mathrm{mmol} \mathrm{kg}^{-1}$ sulfate at 2.5-2.75 mmol kg-1 sulfate in the equilibrium solution. Curtin and Syers (1990) measured adsorbed sulfate at $2.3 \mathrm{mmol} \mathrm{SO}_{4} \mathrm{~kg}^{-1}$ in their subsoil. Gobran et al. (1998) found maimum sulfate adsorption at $2.6 \mathrm{mmol} \mathrm{SO}_{4} \mathrm{~kg}^{-1}$. Autry and Fitzgerald (1993) recorded the sulfate adsorption potential at saturation at $0.83 \mathrm{mmol} \mathrm{SO}_{4} \mathrm{~kg}^{-1}$ for a Bs horizon (Table 3.9). Rose (1998) found that by adding the already existing sulfate and the 
Table 3.9 Comparison of adsorption potentials for different soils.

\begin{tabular}{ccc}
\hline Horizon & $\begin{array}{c}\mathrm{SO}_{4} \text { adsorption } \\
\text { potential at saturation }\end{array}$ & Reference \\
\hline & $\left(\mathrm{mmol} \mathrm{kg}^{-1}\right)$ & \\
Bs & 0.83 & Autry and Fitzgerald (1993) \\
$\mathrm{B}$ & $1.5-2.5$ & Neary et al. (1987) \\
$\mathrm{Bs} 1$ & 2.6 & Gobran et al. (1998) \\
subsoil & 2.3 & Curtin and Syers (1990) \\
Bw2 & $2-3$ & Lusk (1998) \\
B & $1.7-2.4$ & Bryson (2006) \\
\hline
\end{tabular}

adsorption maximum they could conclude that the soil had adsorbed $44 \%$ of its total capacity. Similar results were found for the Otter Creek soils when applying that concept; these soils have adsorbed approximately 30.8 to $41.5 \%$ of their total field capacity. Lusk (1998) using the isotherm method found that the maximum adsorption capacity for soils in the Fernow Experimental Forest was about 2-3 $\mathrm{mmol} \mathrm{kg}^{-1}$ and was able to show sulfate saturation in the Fernow at the initial concentration of $4 \mathrm{mmol} \mathrm{kg}^{-1}$ sulfate. This agrees with the present results where maximum adsorption was found to be between 1.7 and 2.4 $\mathrm{mmol} \mathrm{SO}_{4} \mathrm{~kg}^{-1}$. The similarity of these results indicates the accuracy of the two-point method as the Fernow is adjacent to Otter Creek and the sulfate adsorption of the soils should be similar. The two-point method alleviates concerns about underestimation and oversaturation of the sulfate adsorption capacity, and can be used for large sample sizes. One can determine whether oversaturation is occurring because the equilibrium concentration will remain the same while the adsorption maximum continues to increase. Therefore the adsorption maximum is assumed to be before oversaturation occurs.

\section{Conclusions}

Acid deposition has triggered detrimental changes to the soil in forest ecosystems. Due to the complexities of the system, there is no simple solution to counteract the effects of acid deposition (Marschner et al., 1992). When studying the extent of these negative effects on forest soil, it is essential to determine how sulfate reacts in the soil profile. Studies show that there is a potential for a soil to delay the effects of acid deposition with the ability to retain sulfate. Sulfate contained in acid deposition can cause cation leaching, however, leaching can be reduced if the soil has the capacity to adsorb sulfate. If a soil is able to adsorb sulfate anions then more alkaline cations will remain in the soil 
solution and less of these important soil nutrients will be leached from the system. By measuring the maximum amount of sulfate a soil can adsorb before it becomes saturated, one can determine the soil's capacity to withstand acidification and cation leaching. There are many soil factors that influence the sulfate adsorption capacity's effectiveness in combating acid deposition. Factors affecting sulfate retention can vary according to regional differences that may modify the parent material characteristics and thus alter the soil chemistry in that area (Arbestain et al., 1999). Efforts to map soil sulfate adsorption are hindered by a lack of regional soil information on this property since measures of sulfate adsorption are not routinely performed in soil characterization studies (Johnson and Todd, 1983). Therefore, it is crucial to examine sulfate adsorption in numerous sites with differing parent material and evaluate the variations between the regions to assess how each location is responding to acid deposition.

Through this research the maximum amount of sulfate a soil can retain was determined. By determining this information we can evaluate the current effects of acid deposition on forest soil in this region and the susceptibility of these soils to nutrient depletion and further acidification. Both the single point method and the isotherm method were used to determine the maximum adsorption capacity. The isotherm method gave a more accurate prediction of the saturation point than the single point method. However, the isotherm method was very time consuming so a faster but still accurate method was identified. The two-point method was established by using two sulfate concentrations to calculate the sulfate saturation point. This method was able to predict the maximum sulfate adsorption capacity while still accounting for oversaturation. The two-point method will allow for a fast and accurate representation of the sulfate adsorption capacity and saturation point of forest soils. By using this method, we can obtain critical information on the sulfate saturation index for a wide range of soil types and locations. Therefore, when we map the soils resistance to acidification this important soil property can be accounted for. Furthermore, the lack of method standardization and reporting of detailed soil chemistry make it difficult to compare sulfate adsorption with other soils discussed in the literature. So it is important to determine whether the two-point method will work for soils in different locations. By determining this information we can evaluate the current effects of acid deposition on forest soil and the susceptibility of these soils to 
nutrient depletion and further acidification. 


\section{References}

Adams, M.B., J.A. Burger, A.B. Jenkins, L. Zelazny. 2000. Impact of harvesting and atmospheric pollution on nutrient depletion of eastern US hardwood forests. Forest Ecology and Management. 138:301-319.

Arbestain, M.C., M.E. Barreal, and F. Macias. 1999. Parent material influence on sulfate sorption in forest soils from northwest Spain. Soil Science Society of America Journal. 63:1906-1914.

Autry, A., and J.W. Fitzgerald. 1993. Saturation potentials for sulfate adsorption by fieldmoist forest soils. Soil Biol. Biochem. 25:833-838.

Barton, C.D., A.D. Karathanasis, and G. Chalfant. 2002. Influence of acidic atmospheric deposition on soil solution composition in the Daniel Boone National Forest, Kentucky, U.S.A. Environmental Geology. 41:672-682.

Berger, T.W., and G.E. Likens. 1999. Effects of acid anion additions (trifluoroacetate and bromide) on soil solution chemistry of a northern hardwood forest soil. Water, Air, and Soil Pollution. 116:479-499.

Black, A.S. and S.A. Waring. 1979. Adsorption of nitrate, chlorine, and sulfate by some highly weathered soils from south east Queensland. Australian Journal of Soil Research. 17:271-282.

Blume, J.L., B.A. Schumacher, P.W. Schaffer, K.A. Cappo, L.M. Papp, R.D. Van Remortel, D.S. Coffey, M.G. Johnson, and D.J. Chaloud. 1990. Handbook of Methods for Acid Deposition Studies Laboratory Analyses for Soil Chemistry. USEPA.

Chao, T.T., M.E. Harward, S.F. Fang, 1962. Adsorption and desorption phenomenon of sulfate ions in soils. Soil Sci. Soc. Am. J. 26: 234-237

Charlet, L., N. Dise, and W. Stumm. 1993. Sulfate adsorption on a variable charge soil and reference minerals. Ag. Eco. and Envir. 47: 87-102.

Courchesne, F. and W.H. Hendershot. 1990. The role of basic aluminum sulfate minerals in controlling sulfate retention in the mineral horizons of two spodosols. Soil Science. 150: 571-578. 
Cronan, C.S., R. April, R.J. Bartlett, P.R. Bloom, C.T. Driscoll, S.A. Gherini, G.S. Henderson, J.D. Joslin, J.M. Kelly, R.M. Newton, R.A. Parnell, H.H. Patterson, D.J. Raynal, M. Schaedle, C.L. Schofield, E.I. Sucoff, H.B. Tepper, and F.C. Thornton. 1989. Aluminum toxicity in forests exposed to acidic deposition: the ALBIOS results. Water, Air, and Soil Pollution. 48:181-192.

Curtin, D., and J.K. Syers. 1990. Extractability and adsorption of sulphate in soils. J. Soil Sci. 41:305-312.

Drever, J.I. 1997. The Geochemistry of Natural Waters: Surface and Groundwater Environments, third edition. Prentice Hall. New Jersey. p. 292-306

Drohan, J.R. and W.E. Sharpe. 1997. Long-term changes in forest soil acidity in Pennsylvania, U.S.A. Water, Air, and Soil Pollution. 95:299-311.

Edwards, P.J. 1998. Sulfur cycling: retention, and mobility in soils: a review. USDA Forest Service. NE Research Station. General Technical Report NE-250.

Environmental Protection Agency (EPA). 2006. Clean Air Markets-Progress and Results. Www.epa.gov/airmarkets/cmaps/mapgallery/index.html

Evangelou, V.P. 1998. Environmental Soil and Water Chemistry: Principles and Applications. John Wiley and Son, Inc. New York. p. 141-190

Fuller, R.D., M.B. David, and C.T. Driscoll. 1985. Sulfate adsorption relationships in forested spodosols of the northeastern USA. Soil Sci. Soc Am. J. 49:1034-1040.

Gillman, G.P. 1974. Influence of net charge on water dispersible clay and sorbed sulphate. Aust. J. Soil Res. 12:173-176.

Gobran, G.R., H.M. Selim, H. Hultberg, and I. Andersson. 1998. Sulfate adsorptiondesorption in a Swedish forest soil. Water, Air, and Soil Pollution. 108: 411-424.

Harter, R.D. and R. Naidu. 2001. An assessment of environmental and solution parameter impact on trace-metal sorption by soils. Soil Science Society of America Journal. 65:597-612.

He, L.M., L.W. Zelazny, V.C. Baligar, K.D. Ritchey, and D.C. Martens. 1997. Ionic strength effects on sulfate and phosphate adsorption on $\gamma$-alumina and kaolinite: triple layer model. Soil Sci. Soc. Am. J. 61:784-793.

Hingston, F.J.A., M. Posner, and J.P. Quirk. 1972. Anion adsorption by goethite and 
gibbsite. I. The role of the proton in determining adsorption envelopes. J. Soil. Sci. 23: 177-192.

Hodges, S.C. and G.C. Johnson. 1987. Kinetics of sulfate adsorption and desorption by Cecil soil using miscible displacement. Soil Sci. Soc. Am. J. 51: 323-331.

Huete, A.R., and J.G. McColl. 1984. Soil cation leaching by "acid rain" with varying nitrate-to-sulfate ratios. J. Environ. Qual.13:366-371.

Indorante, S.J., L.R. Follmar, R.D. Hammer, and P.G. Koenig. 1990. Particle size analysis by a modified pipette procedure. Soil Sci. Soc. Am. J. 54:560-563.

Inskeep, W.P. 1989. Adsorption of sulfate by kaolinite and amorphous iron oxide in the presence of organic ligands. J. Enviro. Qual. 18: 379-385.

Jenkins, A. 2001. Organic carbon and fertility of forest soils on the Allegheny Plateau of West Virginia. M.S. Thesis, Department of Plant and Soil Science. West Virginia University.

Johnson, D.W., D.W. Cole, and S.P. Gessel. 1979. Acid precipitation and soil sulfate adsorption properties in a tropical and in a temperate forest soil. Biotropica. $11: 38-42$

Johnson, D.W., D.W. Cole, H. Van Miegroet, and F.W. Horng. 1986. Factors affecting anion movement and retention in four forest soils. Soil Sci. Soc. Am. J. 50:776783.

Johnson, D.W., G.S. Henderson, and D.E. Todd.1981. Evidence of modern accumulations of adsorbed sulfate in an east Tennessee forested Ultisol. Soil Science. 132: 422-426.

Johnson, D.W. and G.E. Taylor. 1989. Role of air pollution in forest decline in eastern North America. Water, Air, and Soil Pollution 48:21-43.

Johnson, D.W. and D.E. Todd. 1983. Relationships among iron, aluminum, carbon, and sulfate in a variety of forest soils. Soil. Sci. Soc. Am. J. 47: 792-800.

Jackson, M.L., H. Kim and L.W. Zelazny.1986. Oxides, Hydroxides, and Aluminosilicates In Methods of Soil Analysis, Part I. Physical and Mineralogical Methods $2^{\text {nd }}$ Ed. Madison. WI.

Kaiser, K. and M. Kaupenjohann. 1998. Influence of the soil solution composition on 
retention and release of sulfate in acid forest soils. Water Air and Soil Pollution 101:363-376.

Karanthanasis, A.D., V.P. Evangelou, and Y.L. Thompson. 1988. Aliminum and iron equilibria in soil solutions and surface waters of acid mine watersheds. Soil Sci. Soc. Am. J. 17:534-543

Kinjo, T. and P.F. Pratt. 1971. Nitrate adsorption: I. In some acid soils of Mexico and South America. Soil Sci. Soc. Am. Proc. 35:722-725.

Kinjo, T. and P.F. Pratt. 1971. Nitrate adsorption: II. In competition with chloride, sulfate,and phosphate. Soil Sci. Soc. Am. Proc. 35:725-728.

Lee, J.J. and D.E. Weber. 1982. Effects of sulfuric acid rain on major cation and sulfate concentrations of water percolating through two model hardwood forests. J. Environ. Qual. 11: 57-64.

Lindsay, W.L. 1979. Chemical Equilibria in Soils. John Wiley \& Sons, New York. p. 35$49,87-117$

Lusk, M.G. 1998. Sulfate dynamics and base cation release in a high elevation Appalachian forest soil. M.S. Thesis, Department of Crop and Soil Environmental Science, Virginia Polytechnic Institute and State University.

MacDonald, N.W. and J.B. Hart, Jr. 1990. Relating sulfate adsorption to soil properties in Michigan forest soils. Soil Sci. Soc. Am. J. 54:238-245.

MacDonald, N.W., A.J. Burton, H.O. Liechty, J.A. Witter, K.S. Pregitzer, G.D. Mroz, and D.D. Richter. 1992. Atmospheric pollutants. Ion leaching in forest ecosystems along a Great Lakes air pollution gradient. J. Environ. Qual. 21:614623.

MacKenzie, J.J. and M.T. El-Ashry. 1989. Air Pollution's Toll on Forests and Crops. Yale University Press. New Haven and London. p. 26-30

Marschner, B., K. Stahr, and M. Renger. 1992. Soil processes and chemical transport. Lime effects on pine forest floor leachate chemistry and element fluxes. J. Environ. Qual. 21: 410-419.

Martinez, C.E., A.W. Kleinschmidt, and M.A. Tabatabai. 1998. Sulfate adsorption by 
variable charge soils: Effect of low-molecular-weight organic acids. Biol Fertil Soils. 26:157-163.

Matzner, E., and N. Dise. 1998. Acidic deposition on forest soils: a threat to the goal of sustainable forestry. Advances in GeoEcology. 31:661-672

McDonald, L.M., and J.A. Balasko. 2003. Temporal trends in $\mathrm{Ca}, \mathrm{Mg}$, and $\mathrm{K}$ concentrations of grassland and garden soils in West Virginia, U.S.A. between 1986 and 1999. Water, Air and Soil Pollution. 146: 351-363.

National Atmosheric Deposition Program (NADP). 2004. Isopleth maps. www.nadp.sws.uiuc.edu/isopleths/maps2004

National Atmospheric Deposition Program (NADP). 2005. Annual and seasonal data summary for site WV18. www.nadp.sws.uiuc.edu/nadpdata/ads.asp? $\mathrm{site}=$ wv18

Neary, A.J., E Mistry, and L. Vanderstar. 1987. Sulphate relationships in some central Ontario forest soils. Can. J. Soil. Sci. 67:341-352

Perrson, P. and L. Lövgren. 1996. Potentiometric and spectroscopic studies of sulfate complexation at the goethite-water interface. Geochemica et Cosmochimica Acta. 60:2789-2799

Pidwirny, M. 2006. Fundamentals of Physical Geography. Ch. 8 Intorduction to the Hydrosphere (h.) Acid Precipitation. www.physicalgeography.net/fundamentals/8h.html

Pierzynski, G., T. Sims, and G.Vance. 2000. Soils and Environmental Quality. 2nd Edition. CRC Press LLC. p. 354-374

Princeton. 2006. Molecular investigation of sulfate complexation in solution and on iron oxide surfaces. http://geoweb.princeton.edu/research/geochemistry/research/aqueous-sulfate.html

Qafoku, N.P. and M.E. Sumner. 2002. Adsorption and desorption of indifferent ions in variable charge subsoils: The possible effect of particle interactions on the counter-ion change density. Soil Sci. Soc. Am. J. 66: 1231-1239.

Rajan, S.S.S. 1978. Sulfate adsorbed on hydrous alumina, ligands displaced, and changes in surface charge. Soil Sci. Soc. Am. J. 42: 39-44.

Reuss, J.O. and D.W. Johnson. 1986. Acid Deposition and the Acidification of Soils and Waters. Ecological Studies Vol 59. Springer-Verlag, Berlin Heidelberg New York 
Rose, S. 1998. Anion adsorption and desorption characteristics of a Piedmont Ultisol:

Some implications for the fate of sulfate adsorption. Water, Air, and Soil Pollution. 101: 333-347.

Schnably, J. 2003. Soil characterization, classification, and biomass accumulation in the Otter Creek Wilderness. M.S. thesis, Department of Plant and Soil Science, West Virginia University.

Shanley, J.B. 1992. Sulfate retention and release in soils at Panola Mountain, Georgia. Soil Science. 153:499-508.

Singh, B.R. 1984. Sulfate sorption by acid forest soils: 1. Sulfate adsorption isotherms and comparison of different adsorption equations in describing sulfate adsorption. Soil Science. 138:189-197.

Soil Survey Staff. 1996. Soil survey laboratory methods manual. Soil survey investigations report no. 42. version 3.0. National Soil Survey Center. Lincoln, $\mathrm{NE}$

Sparks, D.L. 1995. Environmental Soil Chemistry. Academic Press. New York. p. 64-68

Suarez, E.L. and U.S. Jones. 1982. Atmospheric sulfur as related to acid precipitation and soil fertility. Soil Sci. Soc. Am. J. 46:976-980.

Van Praag, H.J. and F. Weissen. 1985. Aluminum effects on spruce and beech seedlings. I. Preliminary observations on plant and soil. Plant Soil. 83:331-338.

Wolt, J.D. 1981. Sulfate retention by acid sulfate-polluted soils in the Copper Basin area of Tennessee. Soil Sci. Soc. Am. J. 45:283-287.

Wolt, J. 1994. Soil Solution Chemistry. Applications to Environmental Science and Agriculture. John Wiley \& Sons. New York. p. 195-199, 240-244

Zhang, P.C. and D.L. Sparks. 1990. Kinetics of sulfate adsorption/desorption on goethite using pressure-jump relaxation. Soil Sci. Soc. Am. J. 54:1266-1273 